\title{
Bikini or Burkini? The role of swimwear and age as determinants of beach interaction with others
}

Mohamed Sobhy

mohamedsobhy@foc.cu.edu.eg

Faculty of Commerce, Cairo University, Orman, P.O. Box 12613, Gîza, Egypt

Abstract

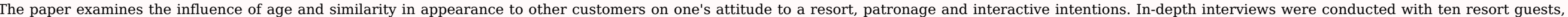

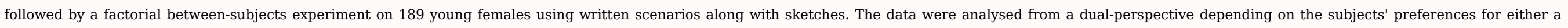

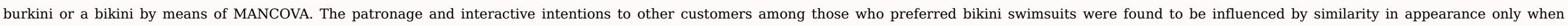

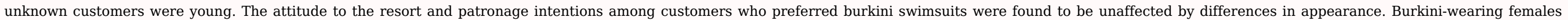
considered similarity in appearance as most important, followed by the age of unknown customers when they formed their interactive intentions toward others.

Keywords: Similarity in appearance; Customer-to-customer interactions; Compatibility management; Elderly customers; Heterogeneous customers; Resorts; Beach experience

\section{Introduction}

"Woman kicked out of Dubai swimming pool for wearing burkini” (Young, 2017)

“Egypt's bikini vs. burkini battle heats up” (Mekky, 2017)

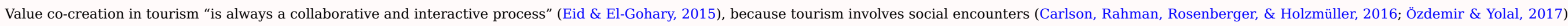

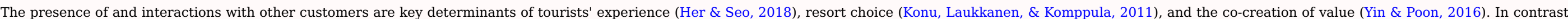
when other tourists are felt to be incompatible with oneself, they may cause social distance (Joo et al., 2018), disturbance and the co-destruction of value (Cai, Lu, \& Gursoy, 2018).

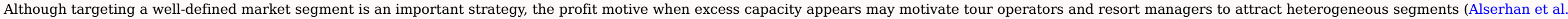

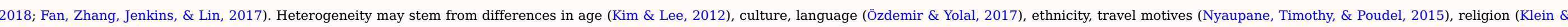

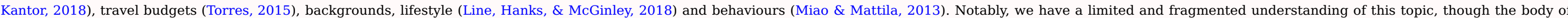
literature is growing.

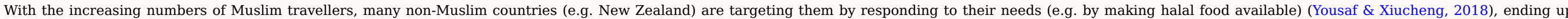

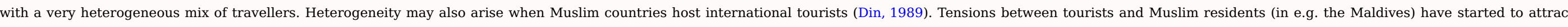

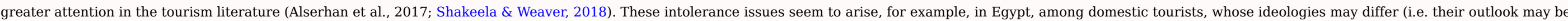

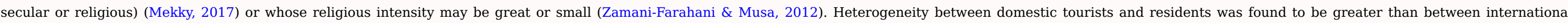

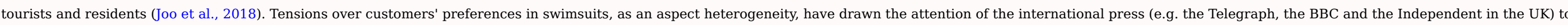

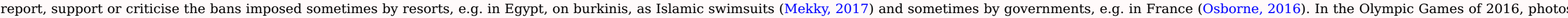

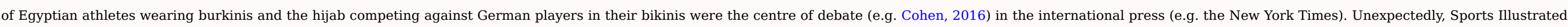

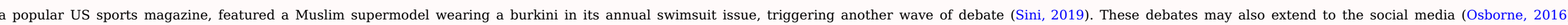
reflecting a clash over identities between secular and religious views (Cohen, 2016). However, in tourism research these tensions are under-represented.

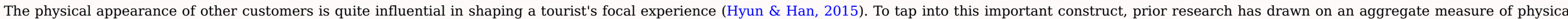




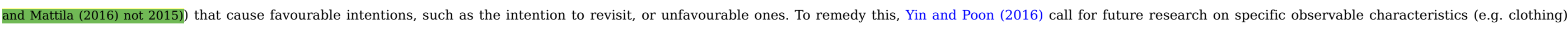

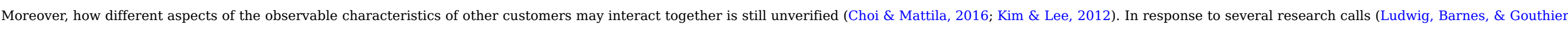

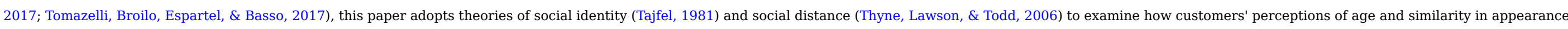

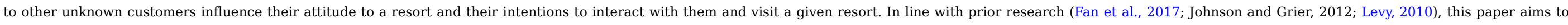
answer this question from a dual perspective (i.e. separating those who prefer bikinis from those who prefer burkini swimsuits).

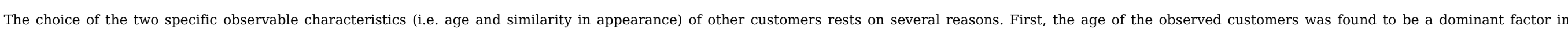

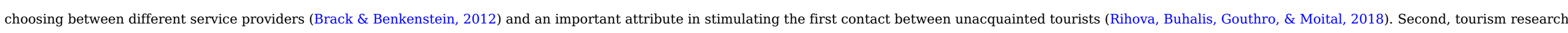

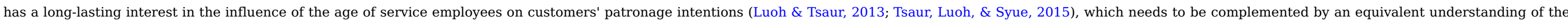

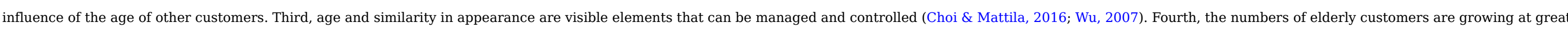

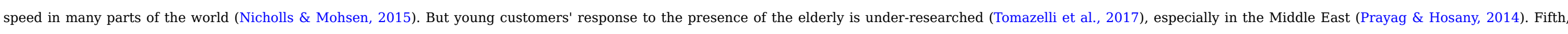

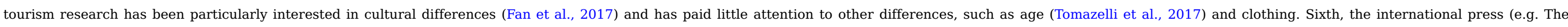
Independent) has paid great attention to tensions over swimsuits in the tourism context (e.g. Osborne, 2016).

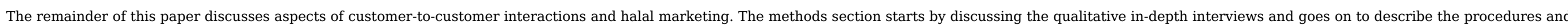
analyse the data from a sketch-based between-subject experiment. The paper concludes with the research implications and suggestions for future research.

\section{Theoretical background}

\subsection{Customer-to-customer interactions}

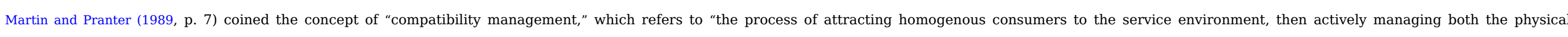

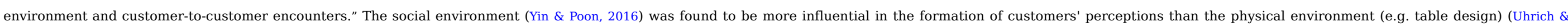
Benkenstein, 2012). Yet it has received scant research attention (Hanks \& Line, 2018).

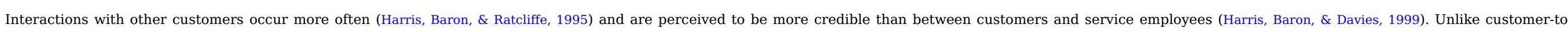

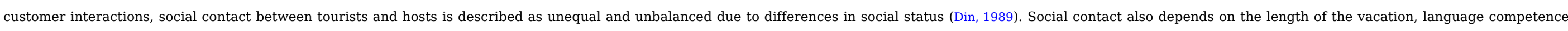

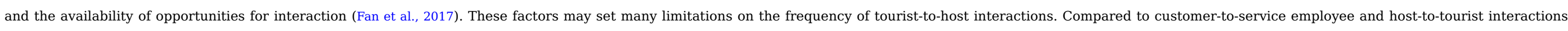

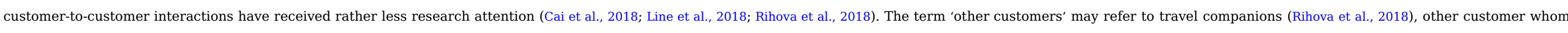

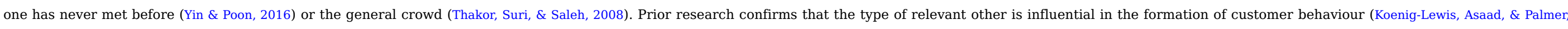
2018).

\subsection{Direct versus indirect customer-to-customer interactions}

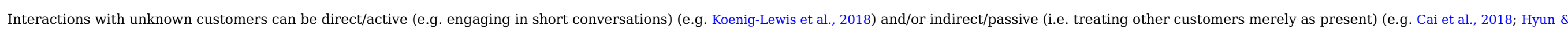

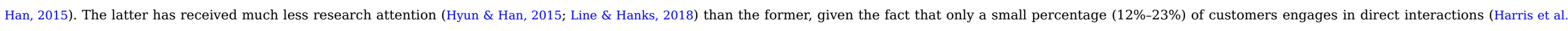

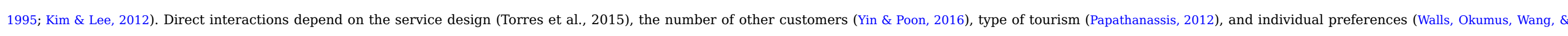

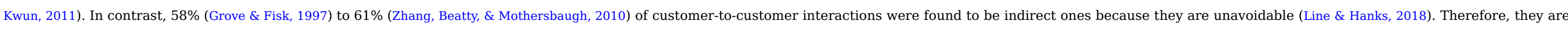
highly influential in customers' experience (Cai et al., 2018; Line \& Hanks, 2018).

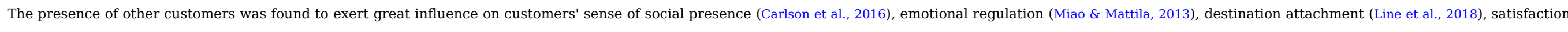

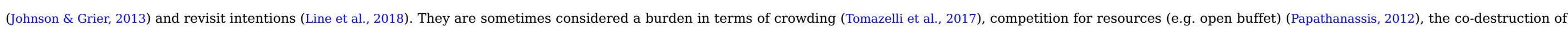
value (e.g. crying babies) (Matson-Barkat \& Robert-Demontrond, 2018) and dysfunctional behaviours (Yin \& Poon, 2016). 


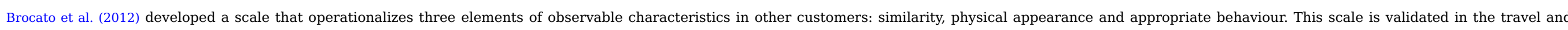

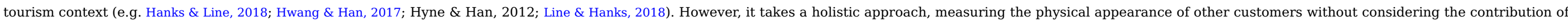

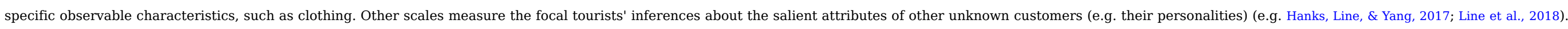
However, it is not clear on what basis (e.g. age) these inferences were made.

\subsection{Halal tourism and indirect customer-to-customer interactions}

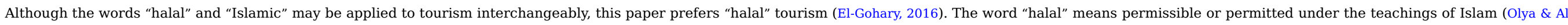

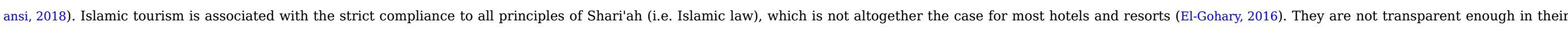
hospitality practices (e.g. in the availability of alcohol) to appeal to both Muslim and non-Muslim tourists (Alserhan et al., 2018).

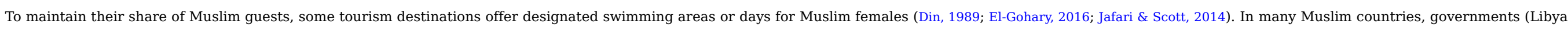

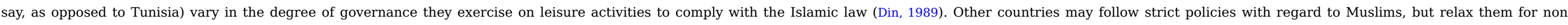
Muslims tourists (e.g. Malaysia) (Din, 1989).

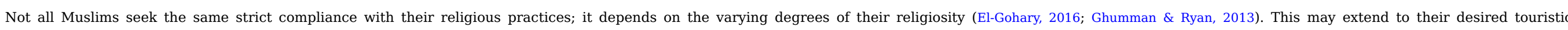

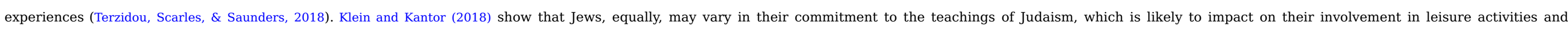
acceptance of dissimilar others.

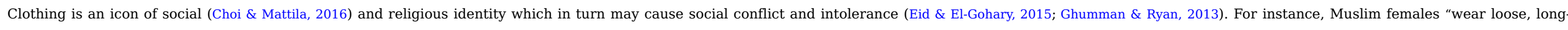

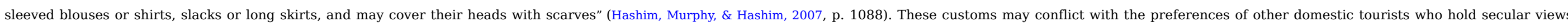

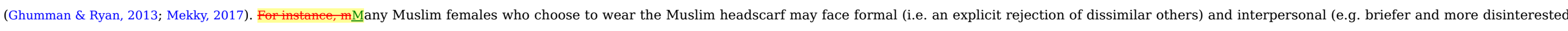

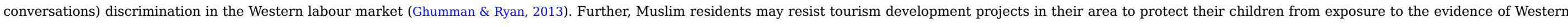

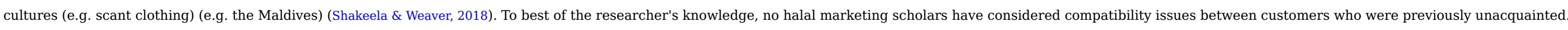

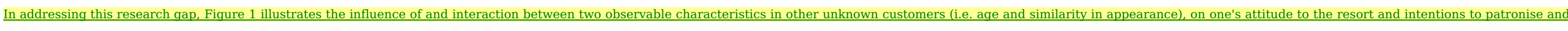

\section{interact with others. (Please relocate figure 1 before sub-section 2.4.)}

\subsection{Age of other customers}

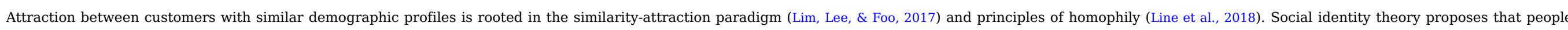

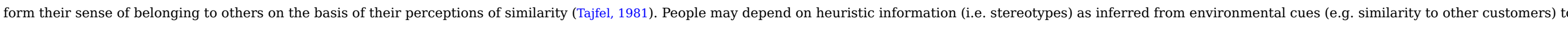
form an attitude about an unfamiliar service provider (Hanks \& Line, 2018; Uhrich \& Benkenstein, 2012).

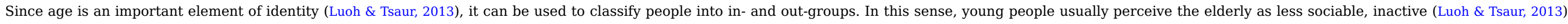
inflexible and not open minded (DeArmond et al., 2006). As a result, young customers rarely prefer to be surrounded by elderly customers (Thakor et al., 2008).

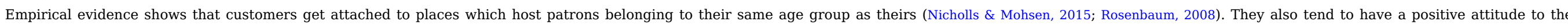

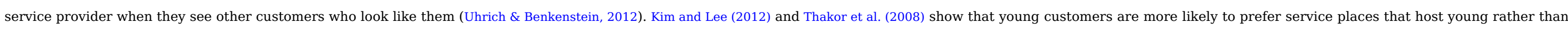
elderly customers. When advertisements feature elderly customers, the purchasing intentions of young customers tend to decline (Day \& Stafford, 1997),

H1. Young customers' attitudes to a resort will be more positive when other unknown customers are young rather than old.

H2. Young customers' patronage intentions will be more positive when other unknown customers are young rather than old.

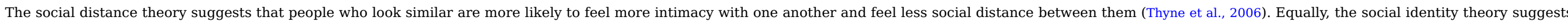

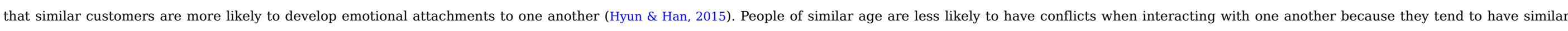




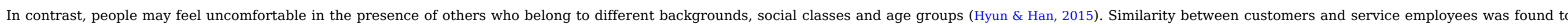

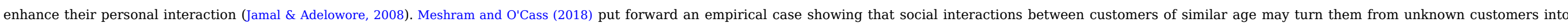
close friends.

H3. Young customers' interactive intentions will be more positive when other unknown customers are young rather than old.

\subsection{Similarity in appearance to other customers}

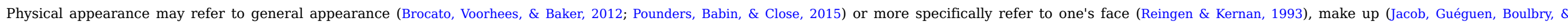

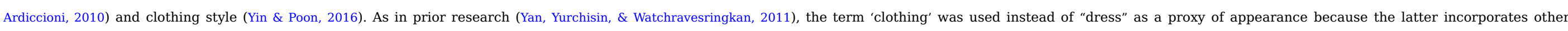
accessories and adornments of the human body such as piercing, which are beyond the focus of this paper. Clothing plays a primary role in forming first impressions (Hamid, 1968).

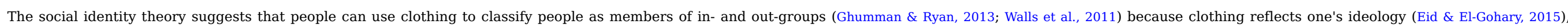

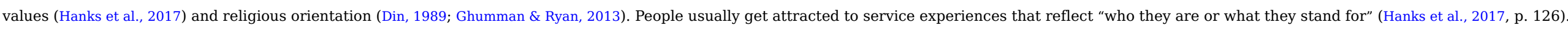

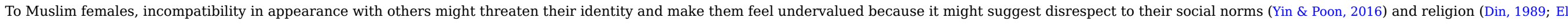

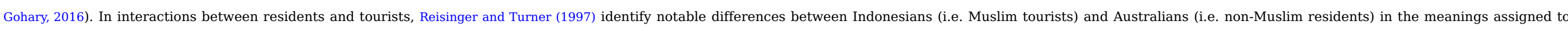

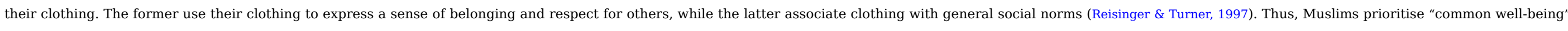

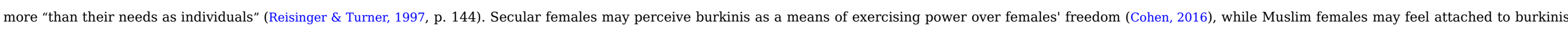
as a means of rejecting "the Western view of beauty and ... sexual objectification of oneself" (Ghumman \& Ryan, 2013, p. 675).

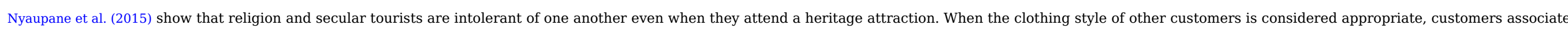

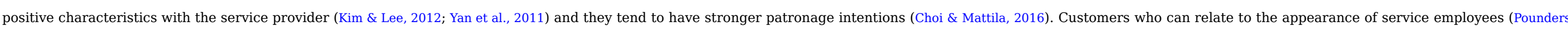
et al., 2015) and other customers (Choi \& Mattila, 2016; Hanks et al., 2017) will develop favourable intentions towards the service provider.

H4. Young customers' attitudes to a resort will be more positive when other unknown customers look similar to them rather than different.

H5. Young customers' patronage intentions will be more positive when other unknown customers look similar to them rather than different.

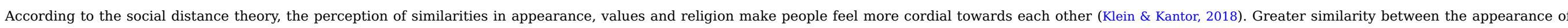

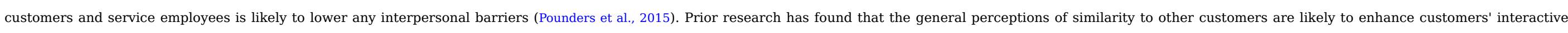

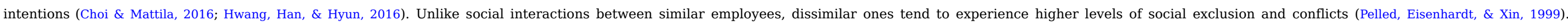
Extending these findings to other aspects of similarity (e.g. clothing), the following hypothesis is concluded.

H6. Young customers' interactive intentions will be more positive when other unknown customers look similar to them rather than different.

\subsection{Interaction effect between age and similarity in appearance to other customers}

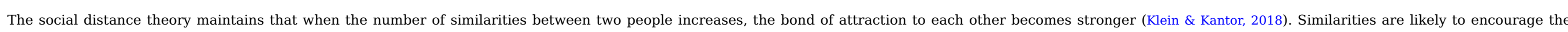

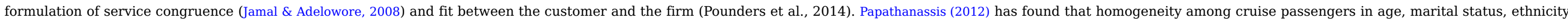

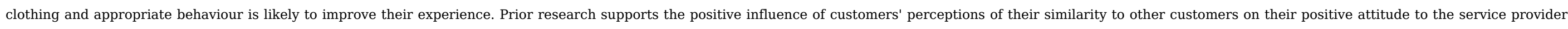
(Hanks et al., 2017; Hanks \& Line, 2018) and patronage intentions (Brack \& Benkenstein, 2014; Choi \& Mattila, 2016).

H7. Young customers' attitudes to the resort will be more positive when other unknown customers are young and look similar to them rather than old and different. 


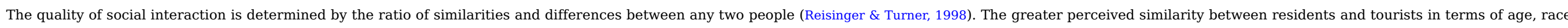

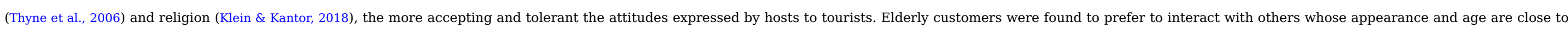

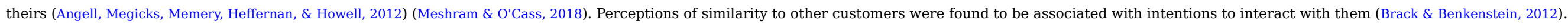

H9. Young customers' interactive intentions will be more positive when other unknown customers are young and look similar to them rather than old and different-

\section{Research context}

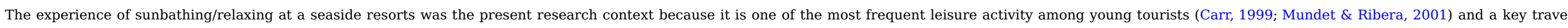

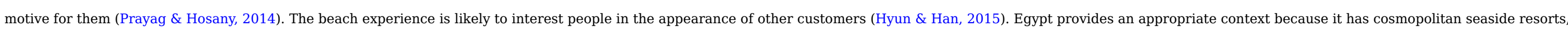

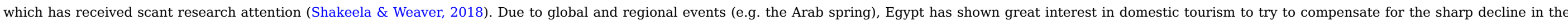

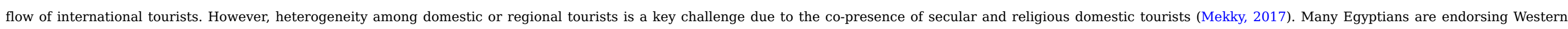
culture and trying to look luxurious and sexy (Al-Mutawa, 2013), while many others in contrast are wholly attached to their religion (Ghumman \& Ryan, 2013).

\section{Methods}

From a post-positivist standpoint, in-depth-interviews were conducted to explore the research phenomena and guide the design of the subsequent experimental study.

\subsection{Study 1: exploratory interviews}

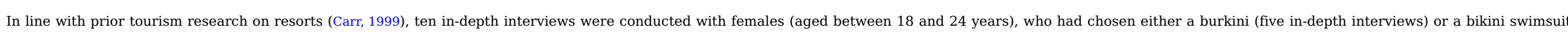

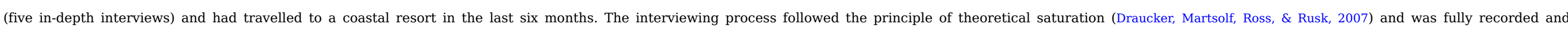

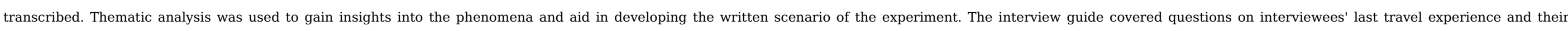
motives for preferring certain swimsuits and then they answered questions about their perceptions and behaviours in response to the presence of unknown customers.

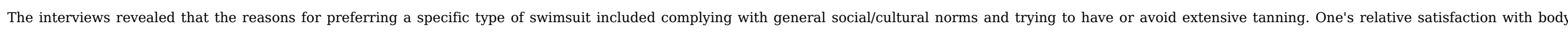

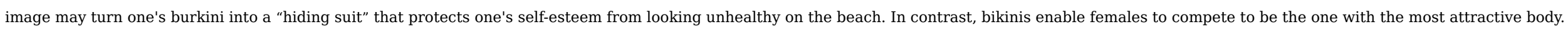

\subsubsection{Intolerance to differences in appearance}

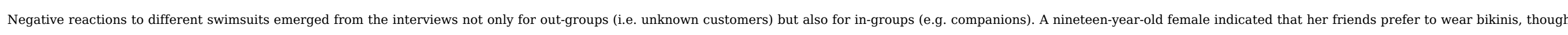
she does not. She thinks that the "burkini gives her personal assurance and a feeling of safety." For unknown customers, interviews consistently demonstrated that differences in swimsuits may cause stress and discomfort.

"It was uncomfortable to see everyone in their bikinis when I am the only one wearing a burkini. I felt like a black sheep ... I stayed at the corner of the pool for 15 minutes and then left." (24 years, burkini wearer)

The qualitative interviews revealed that negative glances are received from others who wear different swimsuits, due to jealousy.

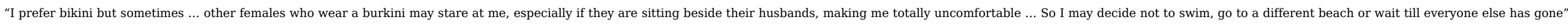
(23 years, bikini wearer)

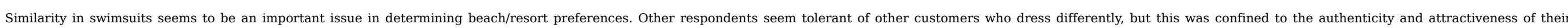
burkinis.

"I am okay with the burkini, but I am not okay with those who swim in their own clothes. There are many fashionable good-looking burkinis!" (21 years, bikini wearer)

"I dislike girls who wear swimsuits that look like burkinis" (22 years, bikini wearer). 


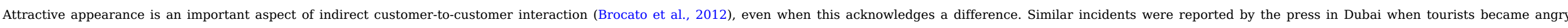
because of a female who was wearing a non-traditional burkini (i.e. one that did not fit the body) (Young, 2017).

\subsubsection{Tolerance of the elderly}

Most of the interviewees were consistent in claiming that they do not have a problem with elderly unknown people.

"My mother and grandmother are my friends. So I can relate to other ladies of their age. I can happily engage in a conversation with strangers, regardless of their age" (23 years, burkini wearer).

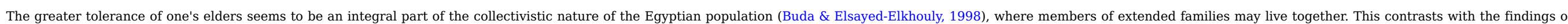
prior studies that young customers always feel intolerant in the presence of the elderly (e.g. Thakor et al., 2008).

\subsubsection{Other aspects of similarity}

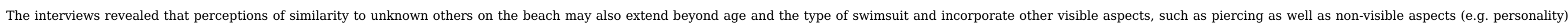
which may act as social clues to determine whether they are compatible.

"On the beach, I talk to others who look and talk like me ... it is a personality thing ... piercing may stop me from interacting with someone I don't know because I hate it" (22 years, bikini wearer).

\subsection{Study 2: experimental design}

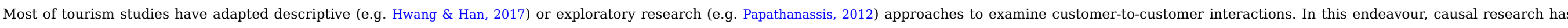

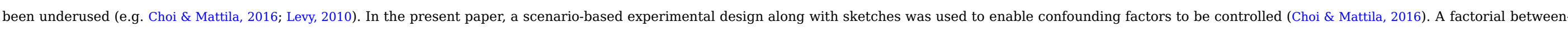

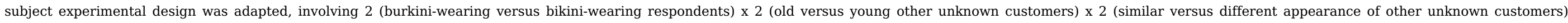

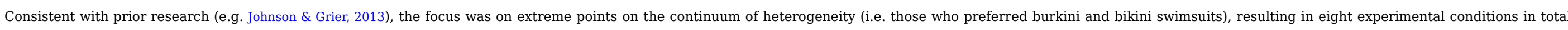

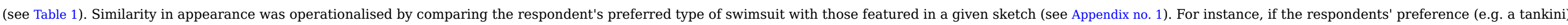
was different from those featured in the sketch (e.g. a bikini), they were discarded.

Table 1 Cross tabulation between age and similarity in appearance across Bikini-wearing and Burkini-wearing samples.

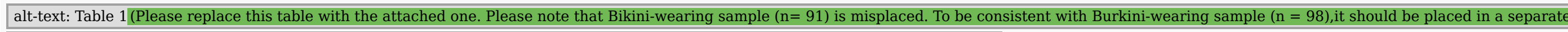
line/row (in the third row) just below the shaded/gray row containing "similar" and "different" labels, as depicted in the attached table.)

Bikini-wearing sample $(\mathrm{n}=91)$

Similar

Appearance of other customers

Different
Age of other customers

Young

Elderly

Total

Burkini-wearing sample $(\mathrm{n}=98)$

Age of other customers

Total

\begin{tabular}{|l|}
\hline 23 \\
\hline 21 \\
\hline 44 \\
\hline 25 \\
\hline 49 \\
\hline
\end{tabular}

49

\begin{tabular}{|l|l|}
\hline 24 & 47 \\
\hline 23 & 44 \\
\hline 47 & 91 \\
\hline 25 & 50 \\
\hline 24 & 48 \\
\hline 49 & 98 \\
\hline
\end{tabular}

\subsubsection{Setup}




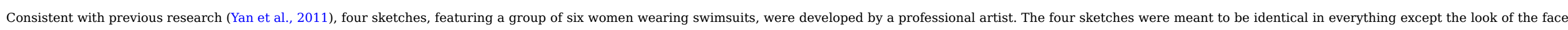
body skin (i.e. meant to reflect age), and the type of swimsuit. The sketches were pretested among three different samples (50 respondents each) to ensure the success of the manipulation.

\subsubsection{Participants}

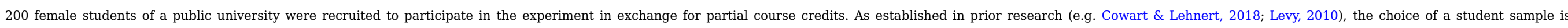

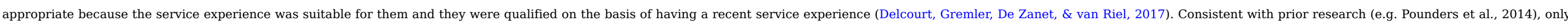

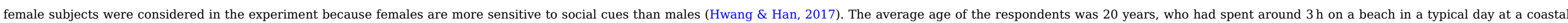

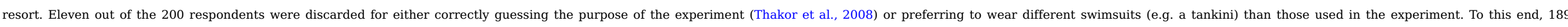
responses were found valid for the data analysis.

\subsubsection{Experimental procedures}

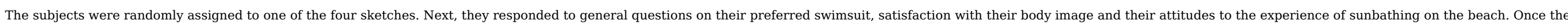

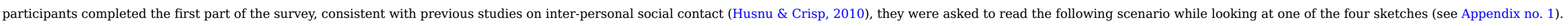

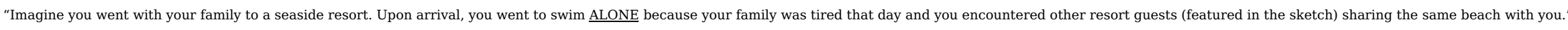

Next, they responded to the realism and manipulation checks and finally to questions related to the dependent variables.

\subsubsection{Control variables}

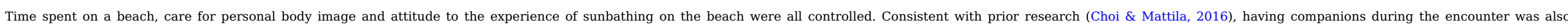
controlled in the scenario because the presence of companions usually makes people less conscious of other customers (Huang \& Hsu, 2010).

\subsubsection{Measurement}

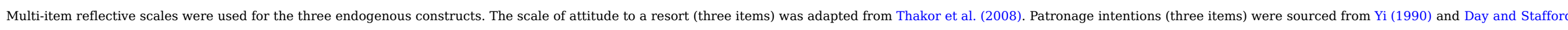

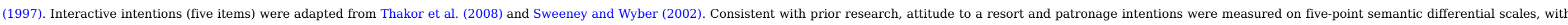

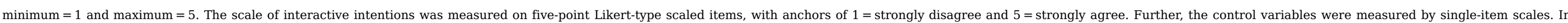

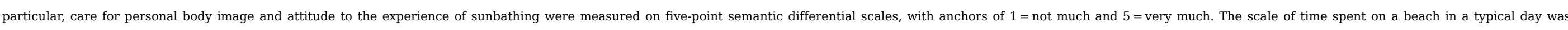
measured by a ratio scale.

\subsubsection{Manipulation and realism checks}

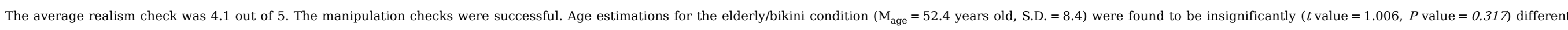

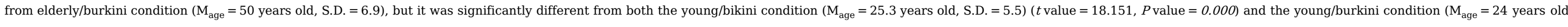

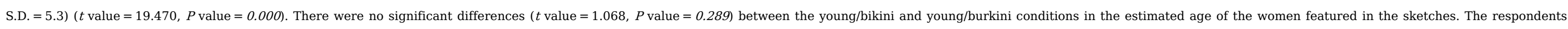
successfully identified the type of swimsuit featured in the sketch.

\section{Data analysis}

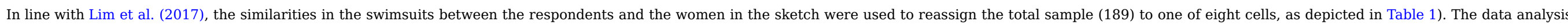

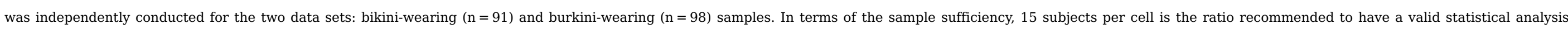
(McGuigan, 1993), which can be satisfied.

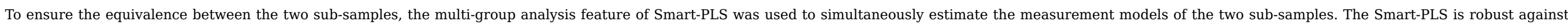




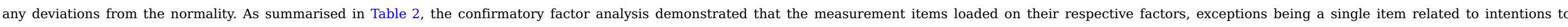
interact.

Table 2 Confirmatory factor loading.

alt-text: Table 2

\begin{tabular}{|c|c|c|c|c|c|c|c|}
\hline & & & kini-wearing sample $(\mathrm{n}=91$ & & & kini-wearing sample $(\mathrm{n}=9$ & \\
\hline & & Loading & Composite Reliability & AVE & Loading & Composite Reliability & AVE \\
\hline Attitude to the resort & & & 0.87 & 0.69 & & 0.93 & 0.83 \\
\hline Bad & good & 0.75 & & & 0.90 & & \\
\hline Unfavourable & favourable & 0.82 & & & 0.93 & & \\
\hline Negative & Positive & 0.91 & & & 0.90 & & \\
\hline Patronage intentions & & & 0.94 & 0.84 & & 0.92 & 0.79 \\
\hline Unlikely & likely & 0.91 & & & 0.95 & & \\
\hline Impossible & possible & 0.93 & & & 0.81 & & \\
\hline Definitely would not & definitely would & 0.89 & & & 0.91 & & \\
\hline Interactive intentions & & & 0.90 & 0.70 & & 0.87 & 0.64 \\
\hline I feel friendly to the ot & & 0.81 & & & 0.79 & & \\
\hline I feel I could talk to th & tch & 0.64 & & & 0.80 & & \\
\hline I feel comfortable witl & its shown in the sketch & 0.93 & & & 0.81 & & \\
\hline I would feel relaxed to & own in the sketch & 0.92 & & & 0.77 & & \\
\hline My experience would & s shown in the sketch & $\ldots$ & & & $\ldots \ldots$ & & \\
\hline
\end{tabular}

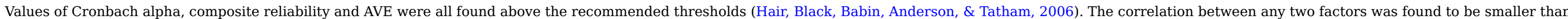

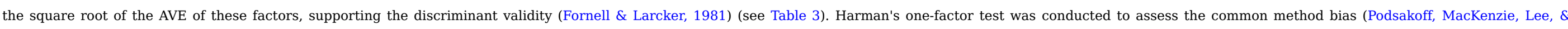
Podsakoff, 2003). The measurement items loaded on three factors, offering no support to the common method bias.

Table 3 The square root of the average variance extracted and the correlation matrix.

alt-text: Table 3

Bikini-wearing sample $(\mathrm{n}=91)$

1

0.83

Interactive intentions

Patronage intentions

Attitude to the resort

$0.45 * *$

$0.41 * *$
2

0.96

$0.37 * *$

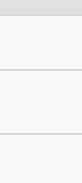

3

0.95

0.80

$0.36 * *$

0.17
Burkini-wearing sample $(\mathrm{n}=98)$

2

0.88

$0.50 * *$

Notes: ${ }^{*} p \leq 0.01, * p \leq 0.05$, the diagonal represents the sq. root of AVE.

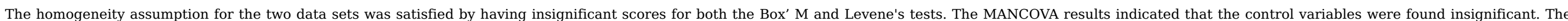




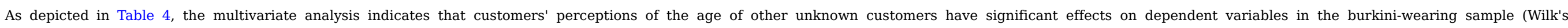
Lambda $=0.912, F$ value $=2.966, P$ value $=0.036, \eta 2=0.088)$, but not the bikini-wearing sample (Wilk's Lambda $=0.964, F$ value $=1.044, P$ value $=0.377, \eta 2=0.036$,

Table 4 Summary of multivariate analysis of variance results.

\begin{tabular}{|c|c|c|c|c|c|c|}
\hline \multicolumn{7}{|c|}{\begin{tabular}{l|l} 
alt-text: Table 4 & (Please replace with the attached \\
example Wilk's Lambda is not well-aligned here))
\end{tabular}} \\
\hline Effect & Wilk's Lambda & $\mathrm{df}_{1}$ & $\mathrm{df}_{2}$ & $F$ & $p$ & $\eta 2$ \\
\hline \multicolumn{7}{|l|}{ Bikini-wearing sample $(\mathrm{n}=91)$} \\
\hline Age & 0.964 & 3 & 87 & 1.044 & 0.377 & 0.036 \\
\hline Similarity & 0.909 & 3 & 87 & 2.853 & $0.042^{*}$ & 0.091 \\
\hline Age x similarity & 0.906 & 3 & 87 & 2.953 & $0.037^{*}$ & 0.094 \\
\hline \multicolumn{7}{|l|}{ Burkini-wearing sample $(\mathrm{n}=98)$} \\
\hline Age & 0.912 & 3 & 94 & 2.966 & $0.036^{*}$ & 0.088 \\
\hline Similarity & 0.917 & 3 & 94 & 2.790 & $0.045^{*}$ & 0.083 \\
\hline Age x similarity & 0.994 & 3 & 94 & 0.170 & 0.917 & 0.006 \\
\hline
\end{tabular}

Notes: $* * 00.01$ (one-sided), ${ }^{*} p \leq 0.05$ (one-sided).

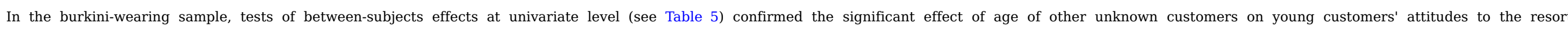

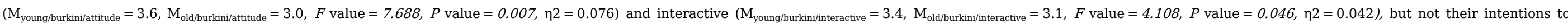
patronise the resort $\left(\mathrm{M}_{\text {young/burkini/patronage }}=3.9, \mathrm{M}_{\text {old } / \text { burkini/patronage }}=3.6, F\right.$ value $=0.023, P$ value $\left.=0.221, \eta 2=0.016\right)$.

Table 5 Summary of Analysis of Variance Results.

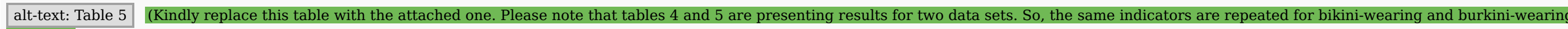
samples.)

$\begin{array}{lll}\text { Sources } & \text { df } \quad \text { Bikini-wearing sample }(n=91)\end{array}$

\begin{tabular}{|c|c|c|c|c|c|c|c|c|c|c|}
\hline & & \multicolumn{3}{|c|}{ Attitude to the resort } & \multicolumn{3}{|c|}{ Patronage intentions } & \multicolumn{3}{|c|}{ Interactive intentions } \\
\hline & & $F$ & $P$ & $\eta 2$ & $F$ & $P$ & $\eta 2$ & $F$ & $p$ & $\eta 2$ \\
\hline Age & 1 & 2.563 & 0.113 & 0.029 & 0.937 & 0.336 & 0.011 & 0.046 & 0.831 & 0.001 \\
\hline Similarity & 1 & 1.030 & 0.313 & 0.012 & 7.278 & $0.008 * *$ & 0.077 & 4.725 & $0.032 *$ & 0.052 \\
\hline Age x similarity & 1 & 5.183 & $0.025 *$ & 0.056 & 4.253 & $0.042 *$ & 0.047 & 4.208 & $0.043 *$ & 0.046 \\
\hline Error & 87 & & & & & & & & & \\
\hline Age & 1 & 7.688 & $0.007 * *$ & 0.076 & 0.023 & 0.221 & 0.016 & 4.108 & $0.046 *$ & 0.042 \\
\hline Similarity & 1 & 3.121 & 0.081 & 0.032 & 0.676 & 0.413 & 0.007 & 7.531 & $0.007 * *$ & 0.074 \\
\hline Age $\mathrm{x}$ similarity & 1 & 0.026 & 0.872 & 0.000 & 0.245 & 0.622 & 0.003 & 0.023 & 0.879 & 0.000 \\
\hline
\end{tabular}


Notes: $* * 00.01$ (one-sided), ${ }^{*} p \leq 0.05$ (one-sided).

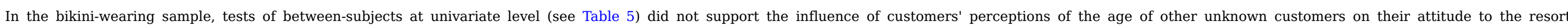

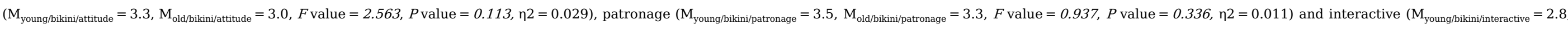
$\mathrm{M}_{\mathrm{old} / \mathrm{bikini} / \text { interactive }}=2.8, F$ value $=0.046, P$ value $\left.=0.831, \eta 2=0.001\right)$ intentions. These results lend partial support to $\mathrm{H} 1$ and $\mathrm{H} 3$ but provide no support to H2.

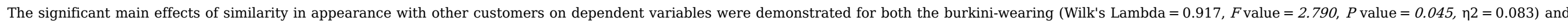

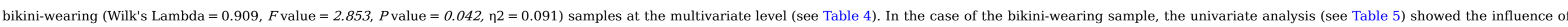

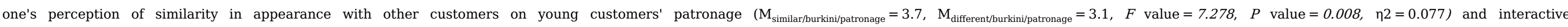

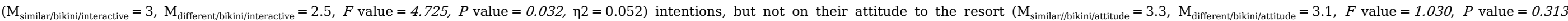
$\eta 2=0.012$ ).

For the burkini-wearing sample, young customers' perception of similarity in appearance with other customers was found to affect young customers' interactive intentions ( $\mathrm{M}_{\mathbf{S}}$ = 3.5, $\mathrm{M}_{\mathrm{dif}}$

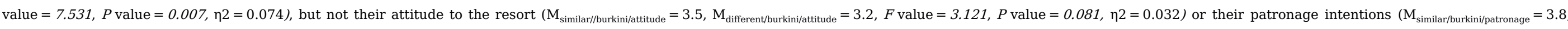
$\mathrm{M}_{\text {different/purkini/patronage }}=3.7, F$ value $=0.676, P$ value $=0.413, \eta 2=0.007$ ) (see Table 5). Consequently, H4 was not supported, but H5 was partially supported. In contrast, H6 was fully supported.

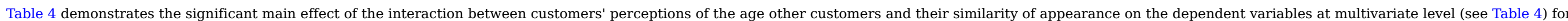

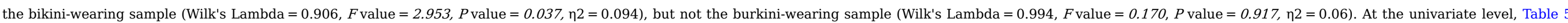

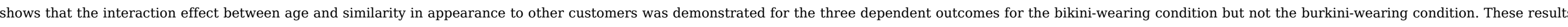
provide partial support for H7, H8 and H9. A summary of the results of hypothesis testing is reported in Table 6 .

Table 6 Testing hypotheses across the Bikini-wearing and Burkini-wearing samples.

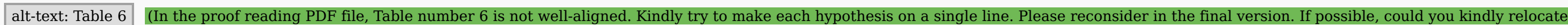
this table before the discussion part as here (not like the PDF).)

\section{Hypotheses testing}

H1: Young customers' attitudes to a resort will be more positive when other unknown customers are young rather than old.

H2: Young customers' patronage intentions will be more positive when other unknown customers are young rather than old.

H3: Young customers' interactive intentions will be more positive when other unknown customers are young rather than old.

H4: Young customers' attitudes to a resort will be more positive when other unknown customers look similar rather than different.

H5: Young customers' patronage intentions will be more positive when other unknown customers look similar rather than different.

H6: Young customers' interactive intentions will be more positive when other unknown customers look similar rather than different.

H7: Young customers' attitudes to a resort will be more positive when other unknown customers are young and look similar to them rather than old and look different.

H8: Young customers' patronage intentions will be more positive when other unknown customers are young and look similar to them rather than old and look different.

H9: Young customers' interactive intentions will be more positive when other unknown customers are young and look similar to them rather than old and look different.

\begin{tabular}{|c|c|c|}
\hline $\begin{array}{c}\text { Bikini-wearing } \\
\text { sample }\end{array}$ & $\begin{array}{l}\text { Burkini-wearing } \\
\text { sample }\end{array}$ & Conclusion \\
\hline - & $\checkmark$ & $\begin{array}{l}\text { Partial } \\
\text { Support }\end{array}$ \\
\hline & - & No support \\
\hline - & $\checkmark$ & $\begin{array}{l}\text { Partial } \\
\text { support }\end{array}$ \\
\hline - & - & No support \\
\hline$\checkmark$ & - & $\begin{array}{l}\text { Partial } \\
\text { support }\end{array}$ \\
\hline$\checkmark$ & $\checkmark$ & Full support \\
\hline$\checkmark$ & - & $\begin{array}{l}\text { Partial } \\
\text { support }\end{array}$ \\
\hline$\checkmark$ & - & $\begin{array}{l}\text { Partial } \\
\text { support }\end{array}$ \\
\hline$\checkmark$ & - & $\begin{array}{l}\text { Partial } \\
\text { support }\end{array}$ \\
\hline
\end{tabular}




\section{Discussion}

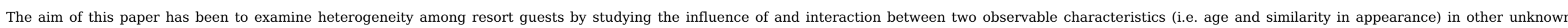

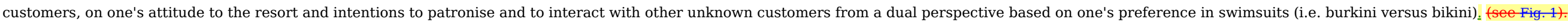

\subsection{Bikini-wearing customers}

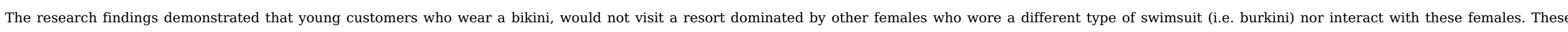

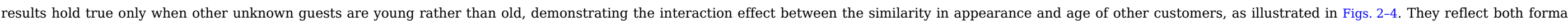

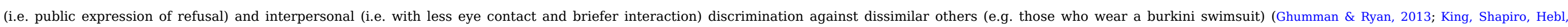

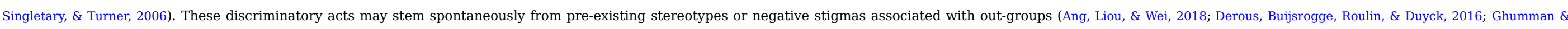
Ryan, 2013; King et al., 2006).(Please relocate figure 1 before section 2.4.)

Conceptual Framework

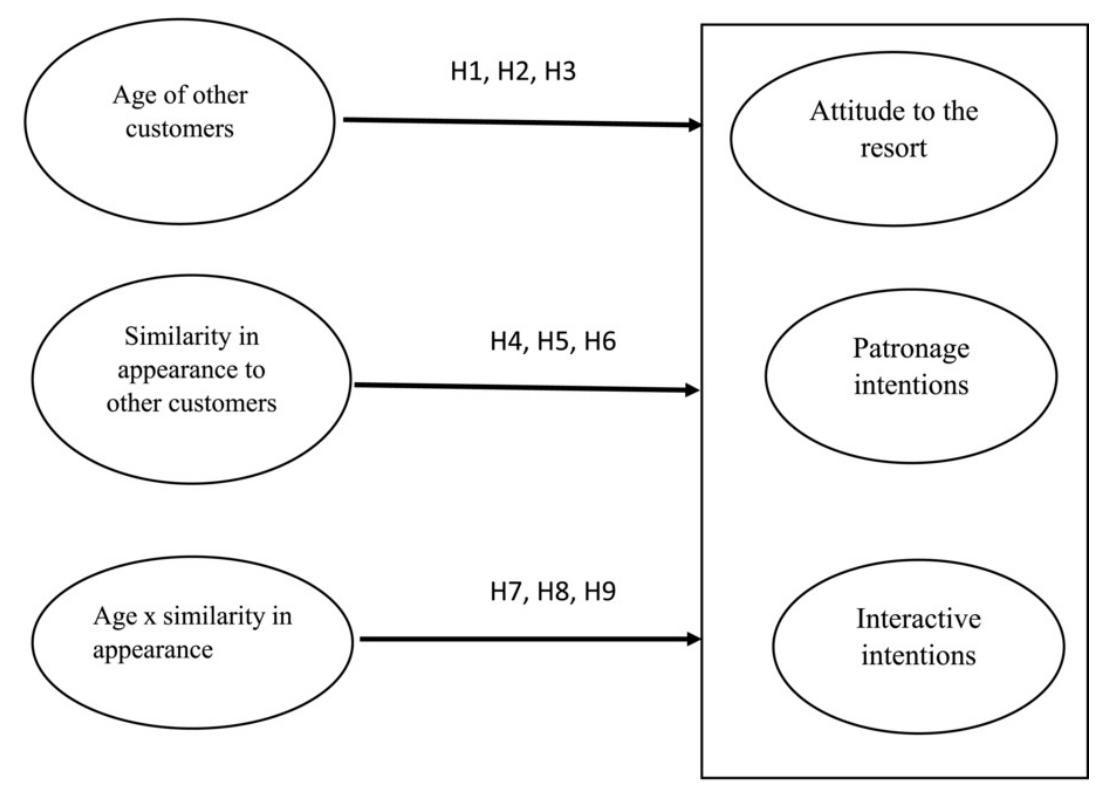

$$
\begin{aligned}
& \text { Covariates: time spent on beach, attitude to the } \\
& \text { experience of sunbathing on the beach, and care } \\
& \text { for the personal body image }
\end{aligned}
$$

Fig. 1 Conceptual framework.

alt-text: Fig. 1 


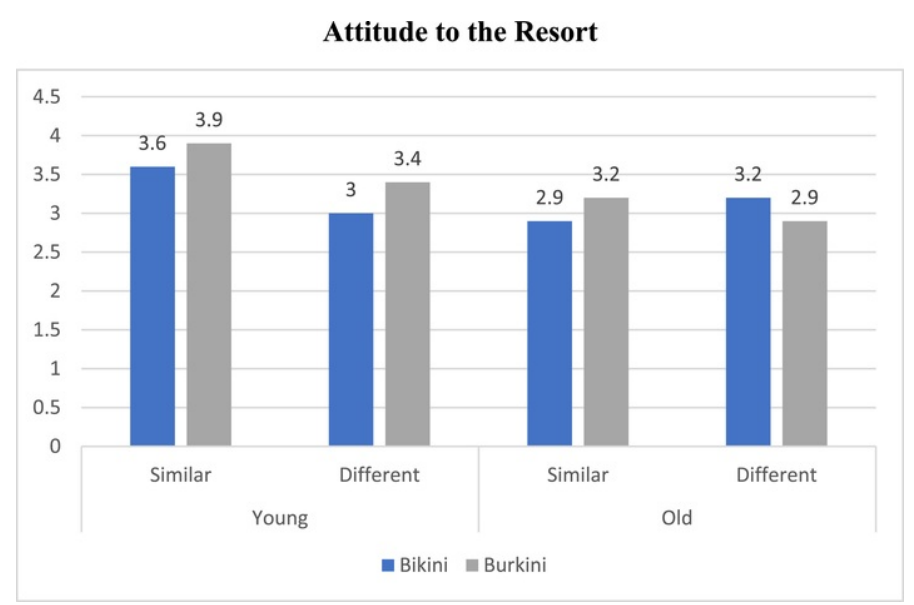

Fig. 2 Attitude to the resort.

alt-text: Fig. 2

Patronage Intentions

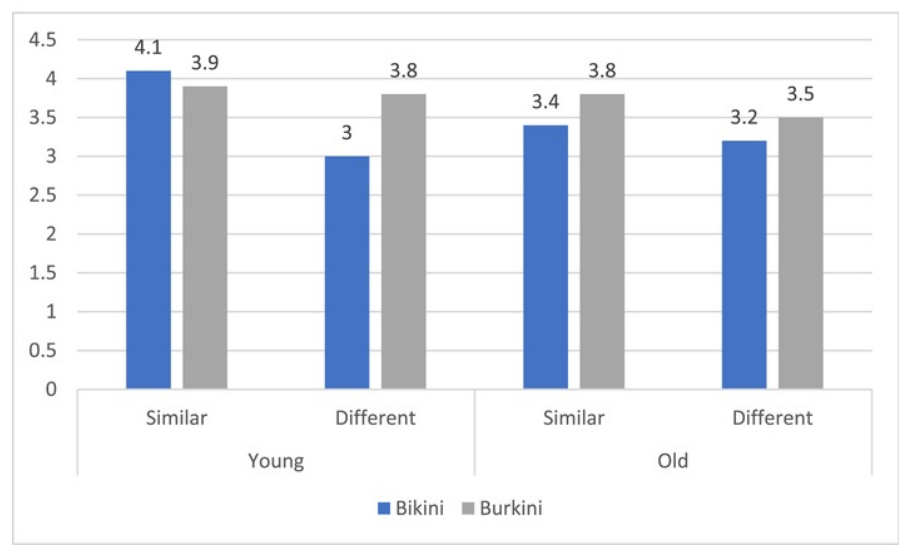

Fig. 3 Patronage intentions.

alt-text: Fig. 3 
Interactive Intentions

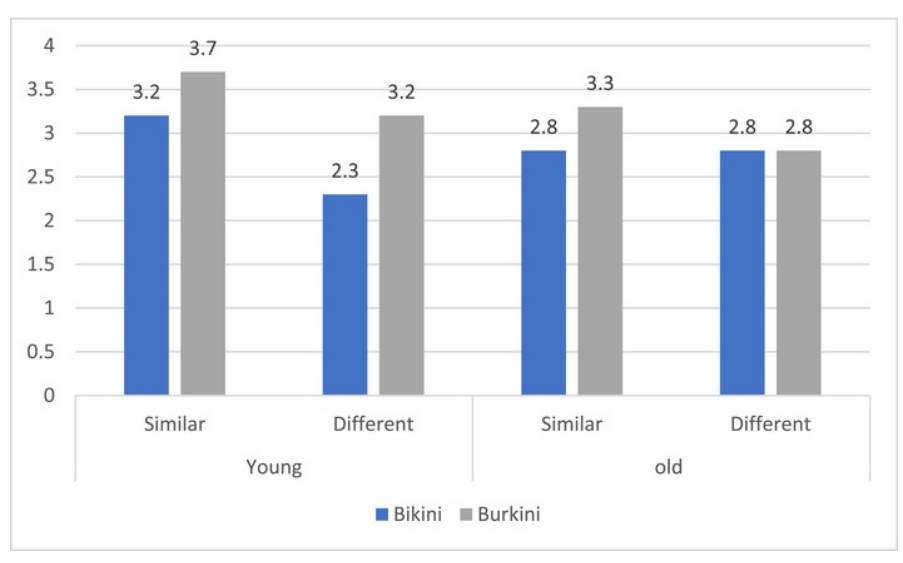

Fig. 4 Interactive intentions.

alt-text: Fig. 4

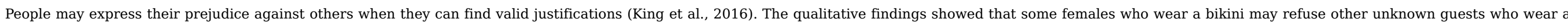

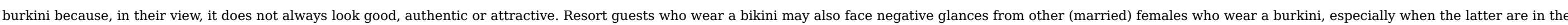

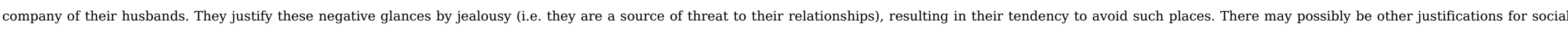

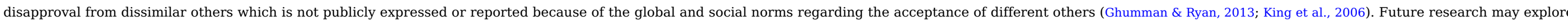
other justifications (e.g. sources of threat, hygiene factors) used by physically dissimilar customers in expressing their refusal to encounter one another.

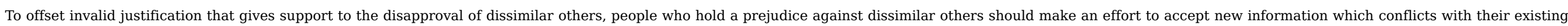

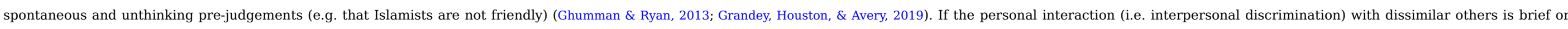

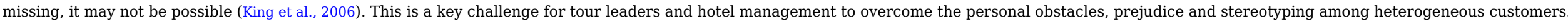

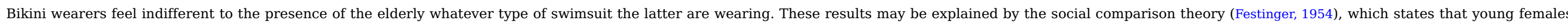
like to show off their beauty to achieve dominance over their eligible rivals. This may indicate the importance of age in determining their sensitivity to differences in appearance.

\subsection{Burkini-wearing customers}

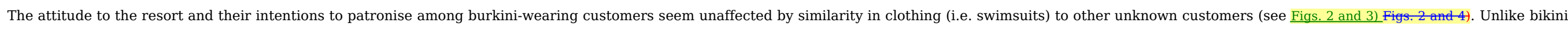

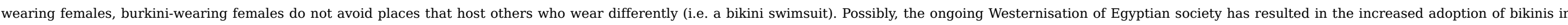

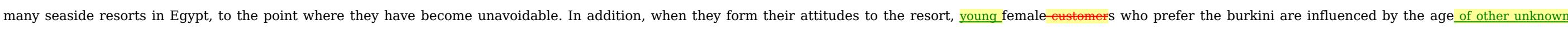

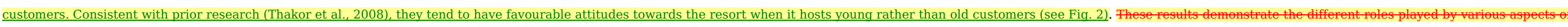
observable characteristies (e.g.age) in other unnm eustomers in the formation of one's rections toward them.

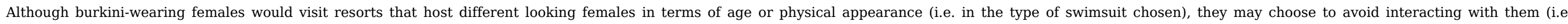

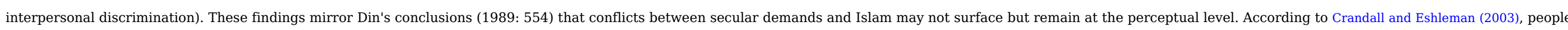

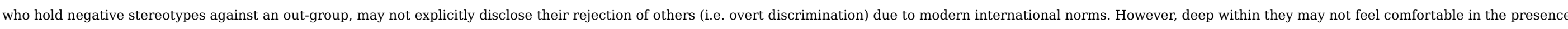
of others belonging to their out-group (Ghumman \& Ryan, 2013; King et al., 2006).

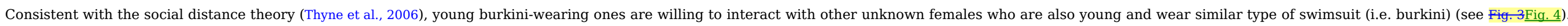




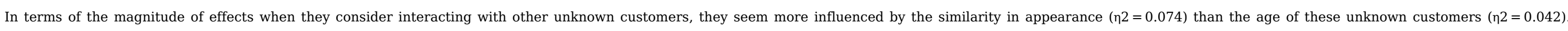

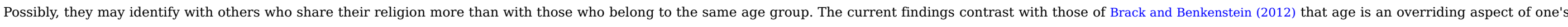

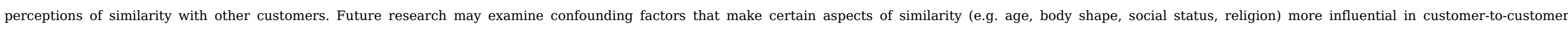
interactions.

\section{Theoretical implications}

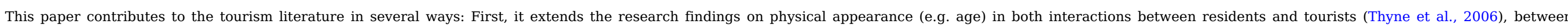

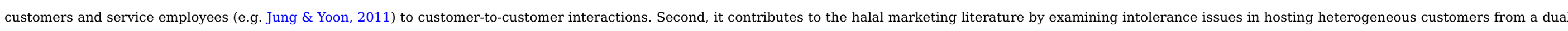

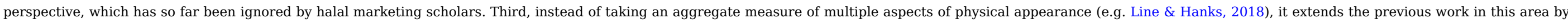

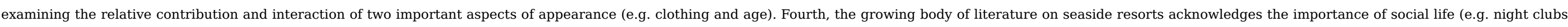

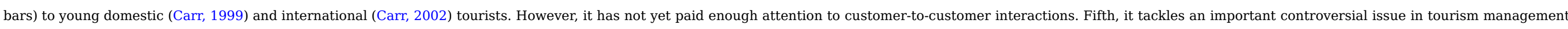

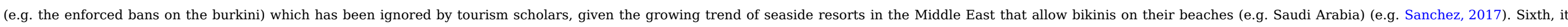

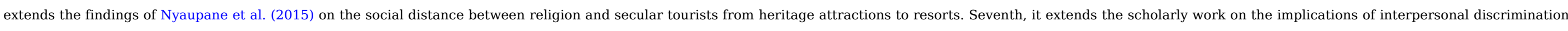

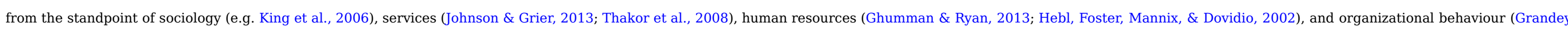
et al., 2019) for tourism management.

\section{Managerial implications}

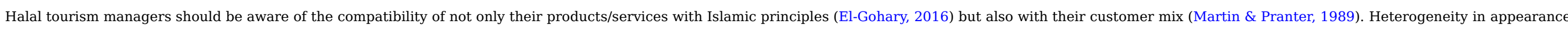

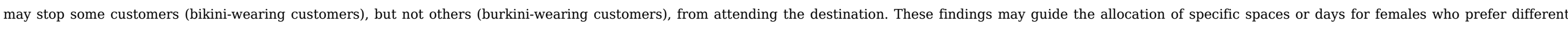

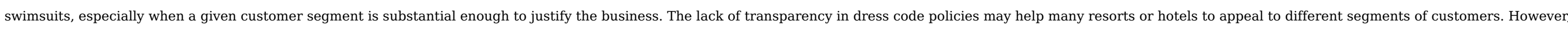
the immediate sales revenues that are generated should be weighed against the long-term financial damage that may occur from conflict incidents between heterogeneous customers (Osborne, 2016).

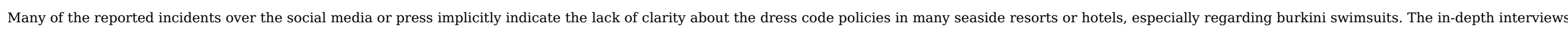

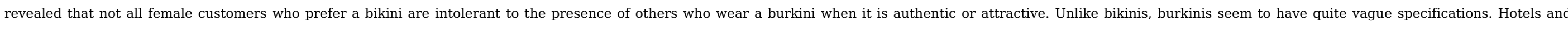

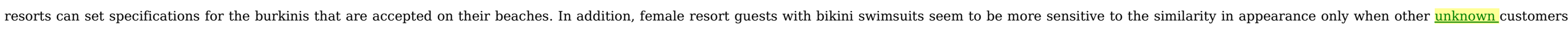
are close in age to theirs. In view of this, resorts may relax their swimsuit restrictions for elderly guests.

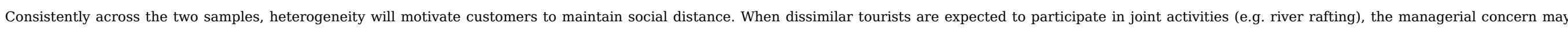

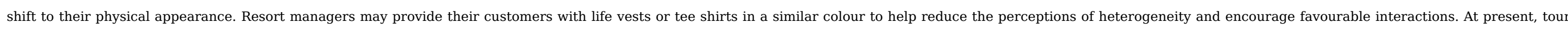

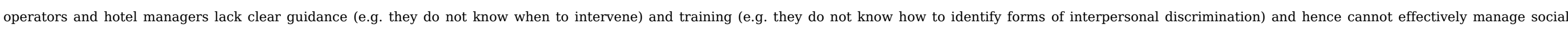

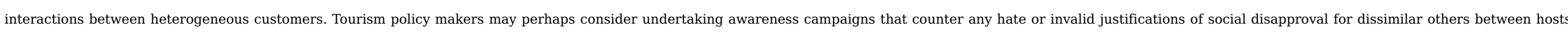
and tourists as well as among heterogeneous tourists.

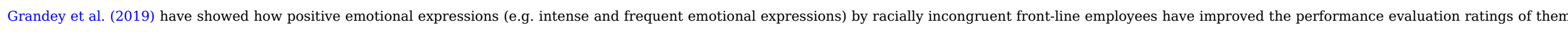

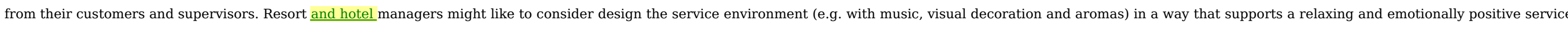

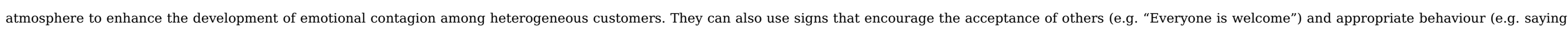

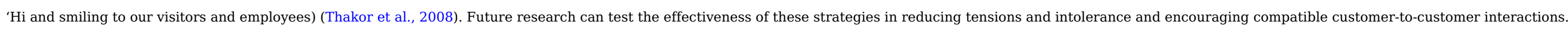

\section{Limitations and directions for future research}

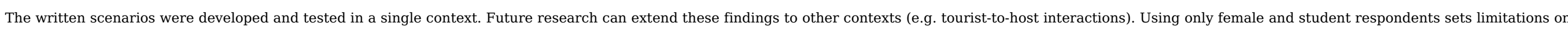

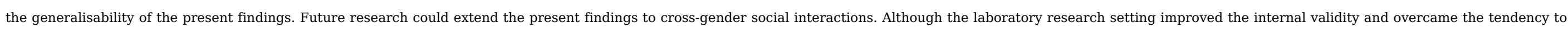




\section{Statement of conflicts of interest}

None.

Author contribution

The manuscript is single authored.

\section{Appendix no. 1. Sketches.}




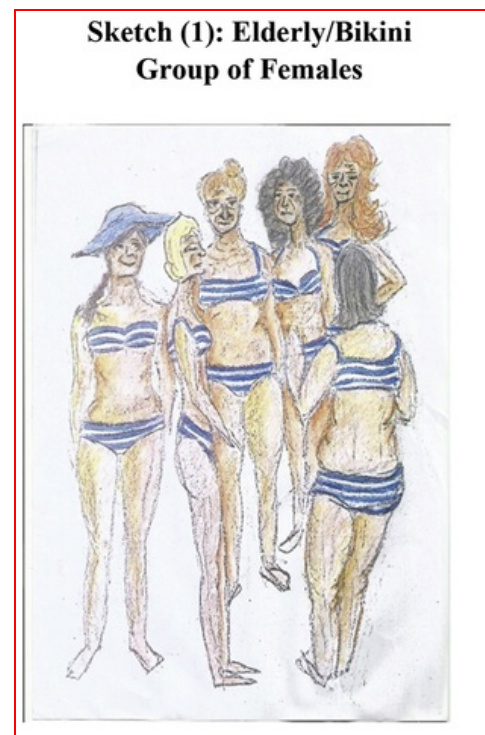

Sketch (2): Young/Bikin Group of Females

Sketch (3): Elderly/Burkini Group of Females

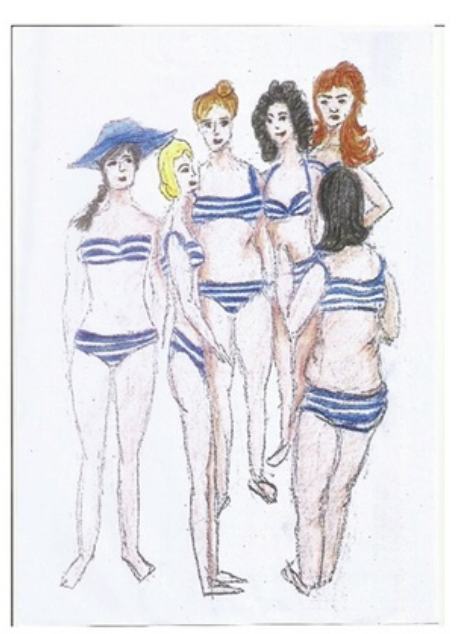

Sketch (4): Young/Burkini Group of Females
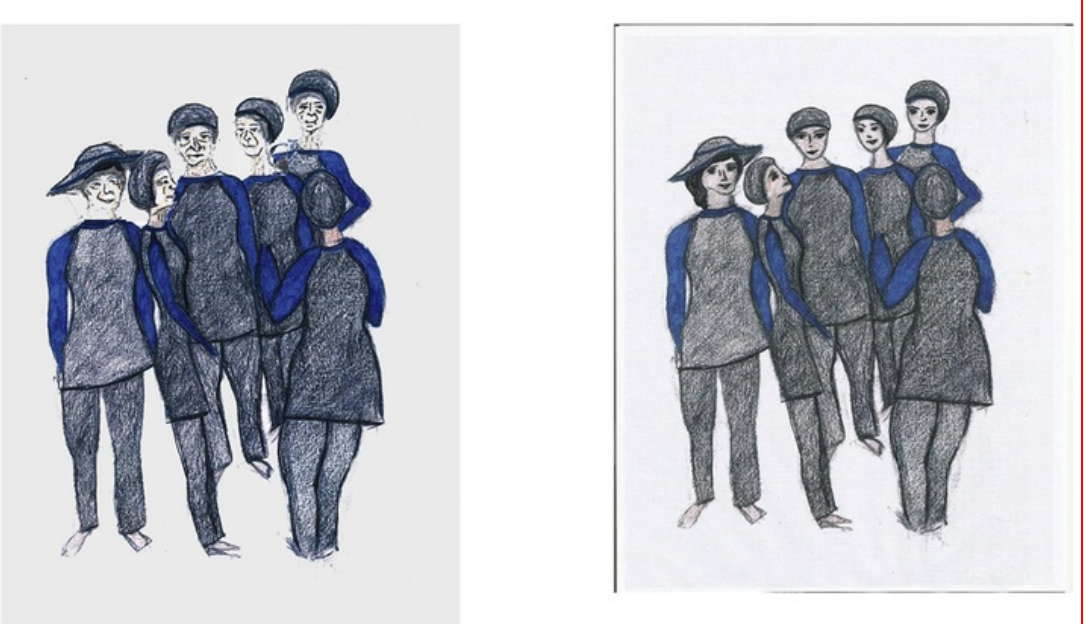

alt-text: Image 2

\section{Appendix no. 2. Descriptive Statistics.}

Measurement items 


3.34

Unfavourable

\section{favourable}

3.09

Negative

\begin{tabular}{l|l|l|l|l|l|}
1.01 & -0.339 & -0.313 & 3.43 & 1.27 & -0.604
\end{tabular}

\begin{tabular}{|l|l|l|l|l|l|}
1.13 & -0.105 & -0.566 & 3.33 & 1.21 & -0.467 \\
\hline
\end{tabular}

Patronage intentions

Unlikely

Impossible

Definitely would not

likely

possible

definitely would

3.26

$1.04 \quad 0.11$

$-0.288$

3.41

$1.18-0.525$

\begin{tabular}{l|l|l|l|}
-0.535 & 3.39 & 1.15 & -0.495
\end{tabular}

\begin{tabular}{l|l|l|l|}
-0.604 & 3.22 & 1.18 & -0.284 \\
\hline
\end{tabular}

$-0.414$

Interactive intentions ${ }^{2}$

I feel friendly to the other resort guests shown in the sketch

I feel I could talk to the other resort guests shown in the sketch

I feel comfortable with the presence of the other resort guests shown in the sketch

I would feel relaxed to swim with the other resort guests shown in the sketch

My experience would be enhanced by the other resort guests shown in the sketch

\begin{tabular}{|l|l|l|}
3.42 & 1.27 & -0.462 \\
\hline
\end{tabular}

$-0.733 \quad 3.78$

\begin{tabular}{|l|l|l|l|}
\hline 3.56 & 1.20 & -0.731 \\
\hline
\end{tabular}

3.43

$-0.184$

3.78

\begin{tabular}{|l|l|l|l|l}
1.21 & -0.925 \\
\hline
\end{tabular}

0.063

\begin{tabular}{|l|l|l|}
\hline 3.34 & 1.11 & -0.250 \\
\hline
\end{tabular}

$-0.665$

\section{Covariates}

How much time do you spend on the beach in a typical day?....hours/day ${ }^{3}$

\begin{tabular}{|l|l|l|l|l|l|l|l|l|l|l|l|}
\hline 2.92 & 1.26 & -0.188 & -1.067 & 3.43 & 1.15 & -0.315 & -0.799 & 3.19 & 1.23 & -0.283 & -0.885 \\
\hline
\end{tabular}

\begin{tabular}{|l|l|l|l|l|l|l|l|l|l|l|l|}
\hline 2.83 & 1.22 & -0.050 & -0.989 & 3.23 & 1.16 & -0.313 & -0.704 & 3.04 & 1.20 & -0.192 & -0.888 \\
\hline
\end{tabular}

\begin{tabular}{|l|l|l|l|l|l|l|}
\hline 2.85 & 1.33 & -0.074 & -1.183 & 3.33 & 1.18 & -0.229 \\
\hline
\end{tabular}

\begin{tabular}{|l|l|l|l|l|l|l|l|l|l|l|l|}
\hline 2.85 & 1.33 & -0.074 & -1.183 & 3.33 & 1.18 & -0.229 & -0.783 & 3.10 & 1.27 & -0.200 & 0.963 \\
\hline 2.78 & 1.30 & 0.083 & -1.066 & 3.16 & 1.22 & -0.044 & -0.822 & 2.97 & 1.27 & -0.007 & -0.948 \\
\hline
\end{tabular}

\begin{tabular}{l|l|l|l|l|}
-0.783 & 3.10 & 1.27 & -0.200 & 0.963 \\
\hline
\end{tabular}

\begin{tabular}{|l|l|l|l|l|l|l|l|}
\hline 2.56 & 1.14 & 0.029 & -1.112 & 2.84 & 1.15 & 0.05 \\
\hline
\end{tabular}

$-0.566$

2.70

1.150 .045

$-0.802$

Do you generally enjoy the experience of sunbathing on the beach ${ }^{4}$

\begin{tabular}{|l|l|l|l|l|l|l|l|l|l|l|l|}
\hline 2.68 & 1.24 & 0.491 & -0.377 & 2.75 & 1.66 & 1.691 & 4.088 & 2.719 & 1.47 & 1.40 & 3.353 \\
\hline 3.84 & 1.06 & -1.724 & 2.695 & 3.79 & 1.16 & -1.502 & 1.542 & 3.820 & 1.11 & -1.591 & 1.958 \\
\hline 3.31 & 0.71 & -0.366 & -0.664 & 3.22 & 0.89 & 0.074 & -0.906 & 3.269 & 0.80 & -1.06 & -0.780 \\
\hline
\end{tabular}

How much do you care about your personal body image?4

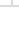

${ }^{1}$ Measured on five-point semantic differential scales, with minimum $=1$ and maximum $=5$.

${ }^{2}$ Measured on five-point Likert-type scaled items, with anchors of $1=$ strongly disagree and $5=$ strongly agree.

${ }^{3}$ Measured by a ratio scale.

${ }^{4}$ Measured on five-point semantic differential scales, with anchors of $1=$ not much and $5=$ very much.

\section{Appendix B. Supplementary data}

Supplementary data to this article can be found online at https://doi.org/10.1016/j.tourman.2019.05.010.

\section{References}

Al-Mutawa F.S., Consumer-generated representations: Muslim women recreating western luxury fashion brand meaning through consumption, Psychology and Marketing 30 (3), 2013, $236-246$.

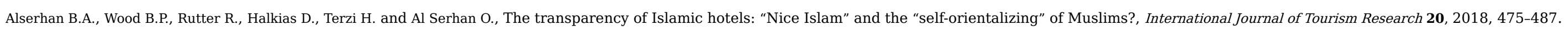
Angell R., Megicks P., Memery J., Heffernan T. and Howell K., Understanding the older shopper: A behavioural typology, Journal of Retailing and Consumer Services 19 (2), 2012 , 259-269. Ang T., Liou R.S. and Wei S., Perceived cultural distance in intercultural service encounters: Does customer participation matter?, Journal of Services Marketing 32 (5), 2018, 547-558. Brack A. and Benkenstein M., The effects of overall similarity regarding the customer-to-customer-relationship in a service context, Journal of Retailing and Consumer Services 19, 2012, 501-509.

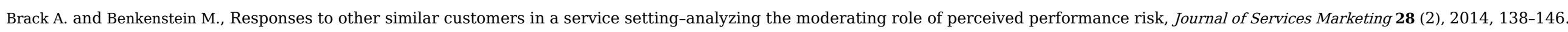

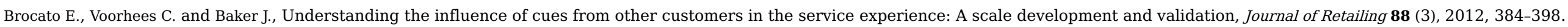


Buda R. and Elsayed-Elkhouly S.M., Cultural differences between Arabs and Americans: Individualism-collectivism revisited, Journal of Cross-Cultural Psychology 29 (3), 1998, 487-492.

Cai R.R., Lu L. and Gursoy D., Effect of disruptive customer behaviors on others' overall service experience: An appraisal theory perspective, Tourism Management 69, 2018, 330-344.

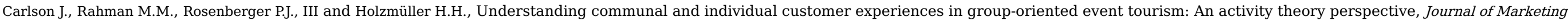
Management 32 (9-10), 2016, 900-925.

Carr N., A study of gender differences: Young tourist behaviour in a UK coastal resort, Tourism Management 20 (2), 1999, $223-228$.

Carr N., A comparative analysis of the behaviour of domestic and international young tourists, Tourism Management 23 (3), 2002, $321-325$.

Choi C. and Mattila A.S., The effects of other customers' dress style on customers' approach behaviors: The moderating role of sense of power, Cornell Hospitality Quarterly 57 (2), 2016 , $211-218$.

Cohen R., Olympians in hijab and bikini, 2016 https://www.nytimes.com/2016/08/12/opinion/olympians-in-hijab-and-bikini.html, Accessed (Accessed on 17 $7^{\text {th }}$ of September, 2018.

Cowart K.O. and Lehnert K.D., Empirical evidence of the effect of colorism on customer evaluations, Psychology and Marketing 35 (5), $2018,357-367$.

Crandall C.S. and Eshleman A., A justification-suppression model of the expression and experience of prejudice, Psychological Bulletin 129 (3), $2003,414-446$.

Day E. and Stafford M., Age-related cues in retail services advertising: Their effects on younger consumers, Journal of Retailing 73 (2), 1997, $211-233$.

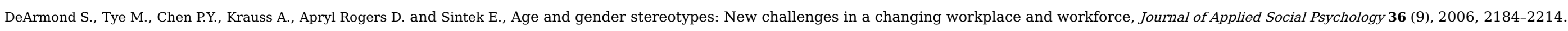

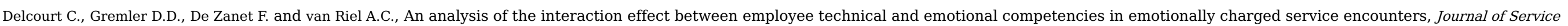

Management 28 (1), 2017, 85-106.

Derous E., Buijsrogge A., Roulin N. and Duyck W., Why your stigma isn't hired: A dual-process framework of interview bias, Human Resource Management Review 26 (2), 2016 , 90-111.

Din K.H., Islam and tourism: Patterns, issues, and options, Annals of Tourism Research 16 (4), 1989, 542-563.

Dion D. and Borraz S., Managing status: How luxury brands shape class subjectivities in the service encounter, Journal of Marketing 81 (5), $2017,67-85$.

Draucker C.B., Martsolf D.S., Ross R. and Rusk T.B., Theoretical sampling and category development in grounded theory, Qualitative Health Research 17 (8), $2007,1137-1148$.

Eid R. and El-Gohary H., Muslim tourist perceived value in the hospitality and tourism industry, Journal of Travel Research 54 (6), $2015,774-787$.

El-Gohary H., Halal tourism, is it really Halal?, Tourism Management Perspectives 19, 2016, 124-130.

Fan D.X., Zhang H.Q., Jenkins C.L. and Lin P.M., Does tourist-host social contact reduce perceived cultural distance?, Journal of Travel Research 56 (8), 2017 , 998-1010.

Festinger L., A theory of social comparison processes, Human Relations 7 (2), 1954, 117-140.

Fornell C. and Larcker D.F., Evaluation structural equation models with unobservable variables and measurement error, Journal of Marketing Research 28, 1981 , 39-50.

Ghumman S. and Ryan A.M., Not welcome here: Discrimination towards women who wear the Muslim headscarf, Human Relations 66 (5), 2013, 671-698.

Grandey A.A., Houston L., III and Avery D.R., Fake it to make it? Emotional labor reduces the racial disparity in service performance judgments, Journal of Management 45 (5), 2019 , $2163-2192$.

Grove S.J. and Fisk R.P., The impact of other customers on service experiences: A critical incident examination of 'getting along, Journal of Retailing 73 (1), $1997,63-85$.

Hair J., Black W., Babin B., Anderson R. and Tatham R., Multivariate data analysis, 6th ed., 2006, Person Prentice Hall; New Jersey.

Hamid P.N., Style of dress as a perceptual cue in impression formation, Perceptual \& Motor Skills 26 (3), 1968, 904-906. 
Hanks L. and Line N.D., The restaurant social servicescape: Establishing a nomological framework, International Journal of Hospitality Management 74, $2018,13-21$.

Hanks L., Line N. and Yang W., Status seeking and perceived similarity: A consideration of homophily in the social servicescape, International Journal of Hospitality Management 60, 2017 , 123-132.

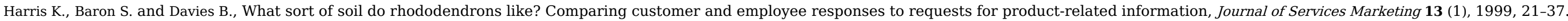

Harris K., Baron S. and Ratcliffe J., Customers as oral participants in a service setting, Journal of Services Marketing 9 (4), 1995, 64-76.

Hashim N., Murphy J. and Hashim N., Islam and online imagery Malaysian tourist destinations websites, Journal of Computer-Mediated Communication 12, 2007, 1082-1102.

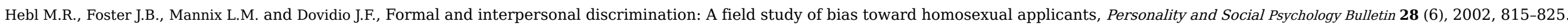

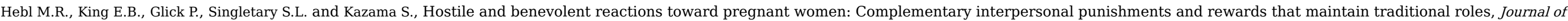
Applied Psychology 92 (6), 2007, 1499-1511.

Her E. and Seo S., Why not eat alone? The effect of other consumers on solo dining intentions and the mechanism, International Journal of Hospitality Management 70, $2018,16-24$.

Huang J. and Hsu H.C., The impact of customer to customer interaction on cruise experience and vacation satisfaction, Journal of Travel Research 49 (1), 2010 , 79-92.

Husnu S. and Crisp R.J., Elaboration enhances the imagined contact effect, Journal of Experimental Social Psychology 46 (6), 2010, 943-950.

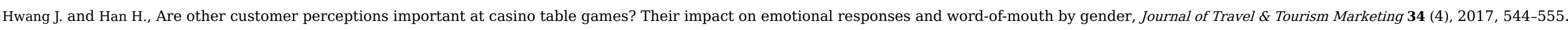

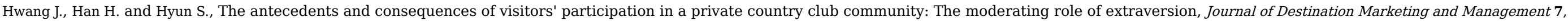
2016, 9-100.

Hyun S.S. and Han H., Luxury cruise travelers: Other customer perceptions, Journal of Travel Research 54 (1), 2015, 107-121.

Jacob C., Guéguen N., Boulbry G. and Ardiccioni R., Waitresses' facial cosmetics and tipping: A field experiment, International Journal of Hospitality Management 29 (1), $2010,188-190$.

Jafari J. and Scott N., Muslim world and its tourism, Annuals of Tourism Research 44, 2014, 1-19.

Jamal A. and Adelowore A., Customer-employee relationship: The role of self-employee congruence, European Journal of Marketing 42, 2008, $1316-1345$.

Johnson G.D. and Grier S.A., Understanding the influence of cross-cultural consumer-to-consumer interaction on consumer service satisfaction, Journal of Business Research 66 (3), 2013 , 306-313.

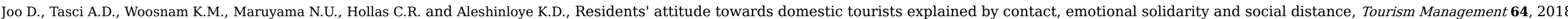
$245-257$.

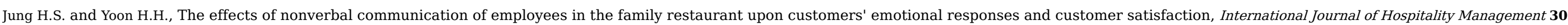
(3), 2011, 542-550.

Kim N. and Lee M., Other customers in a service encounter: Examining the effect in a restaurant setting, Journal of Services Marketing 26 (1), $2012,27-40$.

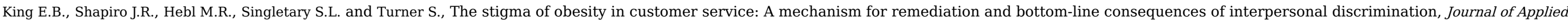
Psychology 91 (3), 2006, 579-593.

Klein G. and Kantor J., How religiosity affects the attitudes of communities towards tourism in a sacred city: The case of Jerusalem, Tourism Management $\mathbf{6 9}$, 2018, $167-179$.

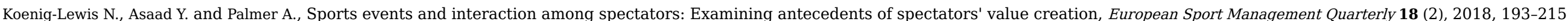

Konu H., Laukkanen T. and Komppula R., Using ski destination choice criteria to segment Finnish ski resort customers, Tourism Management 32 (5), 2011 , $1096-1105$. 


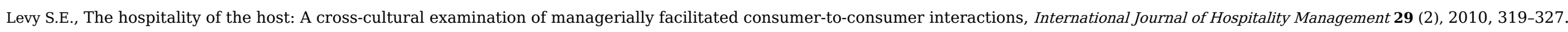

Lim E.A.C., Lee Y.H. and Foo M.D., Frontline employees' nonverbal cues in service encounters: A double-edged sword, Journal of the Academy of Marketing Science 45 (5), 2017, 657-676.

Line N.D. and Hanks L., The social servicescape: A multidimensional operationalization, Journal of Hospitality \& Tourism Research 2018, 1-21.

Line N.D., Hanks L. and McGinley S., When birds flock together: An identification of the destination social servicescape, Journal of Travel \& Tourism Marketing 2018, 1-13.

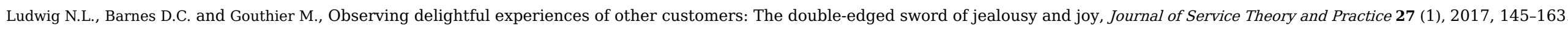

Luoh H. and Tsaur S., The effects of age stereotypes on tour leader roles, Journal of Travel Research 53 (1), 2013, 111-123.

Martin C.L. and Pranter C.A., Compatibility management: Customer-to-customer relationships in service environments, Journal of Services Marketing 3 (3), 1989 , 5-15.

Matson-Barkat S. and Robert-Demontrond P., Who's on the tourists' menu? Exploring the social significance of restaurant experiences for tourists, Tourism Management 69, 2018, 566-578.

McGuigan F.J., Experimental psychology: Methods of research, 1993, Simon and Schuster; Englewood Cliffs, NJ.

Mekky S., Egypt's bikini vs burkini battle heats up, 2017 http://www.arabnews.com/node/1144931/middle-east, Accessed on 12 th of April, 2018.

Meshram K. and O'Cass A., Senior citizens' perspective on the value offerings of third place via customer to customer (C-2-C) engagement, Journal of Services Marketing 32 (2), 2018, 175-194.

Miao L. and Mattila A.S., The impact of other customers on customer experiences: A psychological distance perspective, Journal of Hospitality \& Tourism Research 37 (1), $2013,77-99$.

Mundet L. and Ribera L., Characteristics of divers at a Spanish resort, Tourism Management 22 (5), 2001, 501-510.

Nicholls R. and Mohsen M., Other customer age: Exploring customer age-difference related CCI, Journal of Services Marketing 29 (4), $2015,255-267$.

Nyaupane G.P., Timothy D.J. and Poudel S., Understanding tourists in religious destinations: A social distance perspective, Tourism Management 48, 2015, 343-353.

Olya H.G. and Al-ansi A., Risk assessment of halal products and services: Implication for tourism industry, Tourism Management 65, 2018, 279-291.

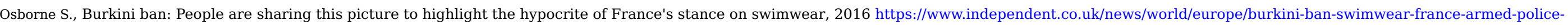
nice-hijab-muslim-a7209091.html, Accessed at 12th of September, 2018.

Özdemir C. and Yolal M., Cross-cultural tourist behavior: An examination of tourists' behavior in guided tours, Tourism and Hospitality Research 17 (3), $2017,314-324$.

Papathanassis A., Guest-to-guest interaction on board cruise ships: Exploring social dynamics and the role of situational factors, Tourism Management 33 (5), 2012, 1148-1158.

Pelled L.H., Eisenhardt K.M. and Xin K.R., Exploring the black box: An analysis of work group diversity, conflict, and turnover, Administrative Science Quarterly 34 (1), 1999 , 21-37.

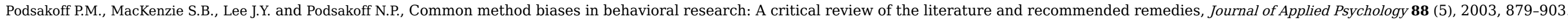

Pounders K., Babin B. and Close A., All the same to me: Outcomes of aesthetic labor performed by frontline service providers, Academy of Marketing Science 15 (6), 2015, 670-693.

Prayag G. and Hosany S., When Middle East meets West: Understanding the motives and perceptions of young tourists from United Arab Emirates, Tourism Management 40, 2014 , 35-45.

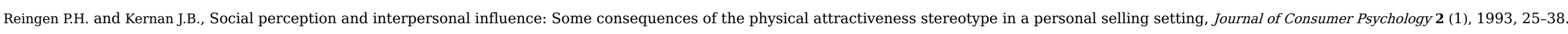

Reisinger Y. and Turner L., Cross-cultural differences in tourism: Indonesian tourists in Australia, Tourism Management 18 (3), 1997, $139-147$.

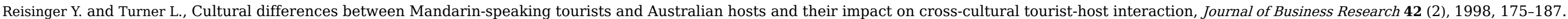

Rihova I., Buhalis D., Gouthro M.B. and Moital M., Customer-to-customer co-creation practices in tourism: Lessons from Customer-Dominant logic, Tourism Management 67, 2018, 362-375. 
Rosenbaum M., Return on community for consumers and service establishments, Journal of Service Research 11 (2), 2008, 179-196.

Rosenbaum M.S. and Montoya D.Y., Am I welcome here? Exploring how ethnic consumers assess their place identity, Journal of Business Research 60 (3), $2007,206-214$.

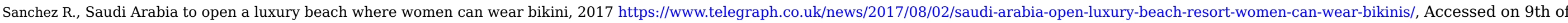
September 2018.

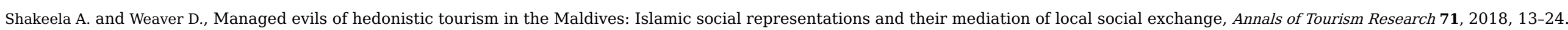

Sini R., Sports Illustrated features the first burkini girl, 2019 https://www.bbc.com/news/48071948, Accessed at $11^{\text {th }}$ of May, 2019.

Sweeney J.C. and Wyber F., The role of cognitions and emotions in the music-approach-avoidance behavior relationship, Journal of Services Marketing 16 (1), $2002,51-69$.

Tajfel H., Human groups and social categories: Studies in social psychology, 1981, CUP Archive.

Terzidou M., Scarles C. and Saunders M.N., The complexities of religious tourism motivations: Sacred places, vows and visions, Annals of Tourism Research 70, $2018,54-65$.

Thakor M., Suri R. and Saleh K., Effects of service setting and other consumers' age on the service perceptions of young consumers, Journal of Retailing $\mathbf{8 4}$ (2), 2008 , $137-149$.

Thyne M., Lawson R. and Todd S., The use of conjoint analysis to assess the impact of the cross-cultural exchange between hosts and guests, Tourism Management 27 (2), $2006,201-213$.

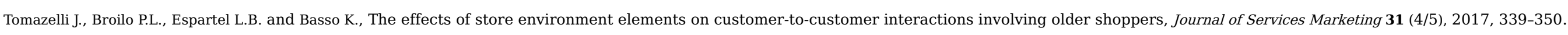

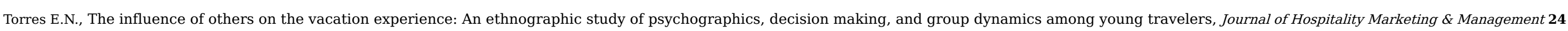

(8), 2015, 826-856.

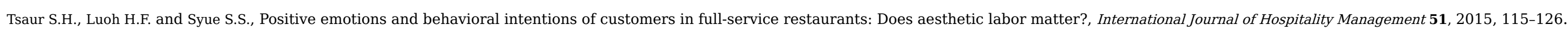

Uhrich S. and Benkenstein M., Physical and social atmospheric effects in hedonic service consumption: Customers' roles at sporting events, Service Industries Journal 32 (11), $2012,1741-1757$.

Walls A., Okumus F., Wang Y. and Kwun D.J.W., Understanding the consumer experience: An exploratory study of luxury hotels, Journal of Hospitality Marketing \& Management 20 (2), 2011, 166-197.

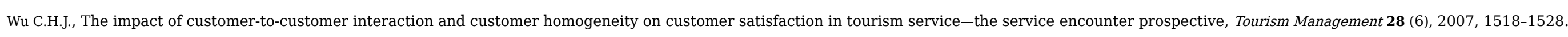

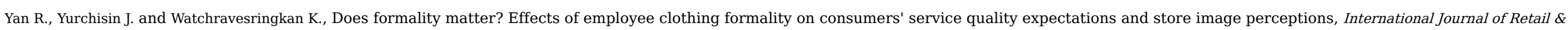
Distribution Management 39 (5), 2011, 346-362.

Yi Y., Cognitive and affective priming effects of the context for print advertisements, Journal of Advertising 19 (2), 1990, 40-48.

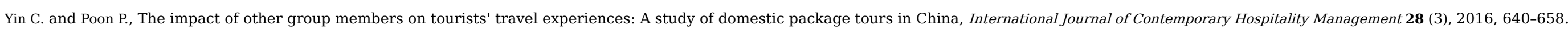

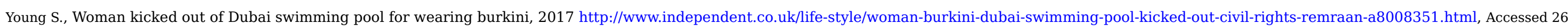
February 2018.

Yousaf S. and Xiucheng F., Halal culinary and tourism marketing strategies on government websites: A preliminary analysis, Tourism Management $\mathbf{6 8}$, 2018 , 423-443.

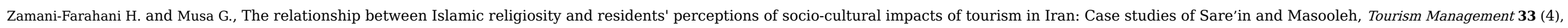
2012, 802-814.

Zhang J., Beatty S.E. and Mothersbaugh D., A CIT investigation of other customers' influence in services, Journal of Services Marketing 24 (5), $2010,389-399$. 


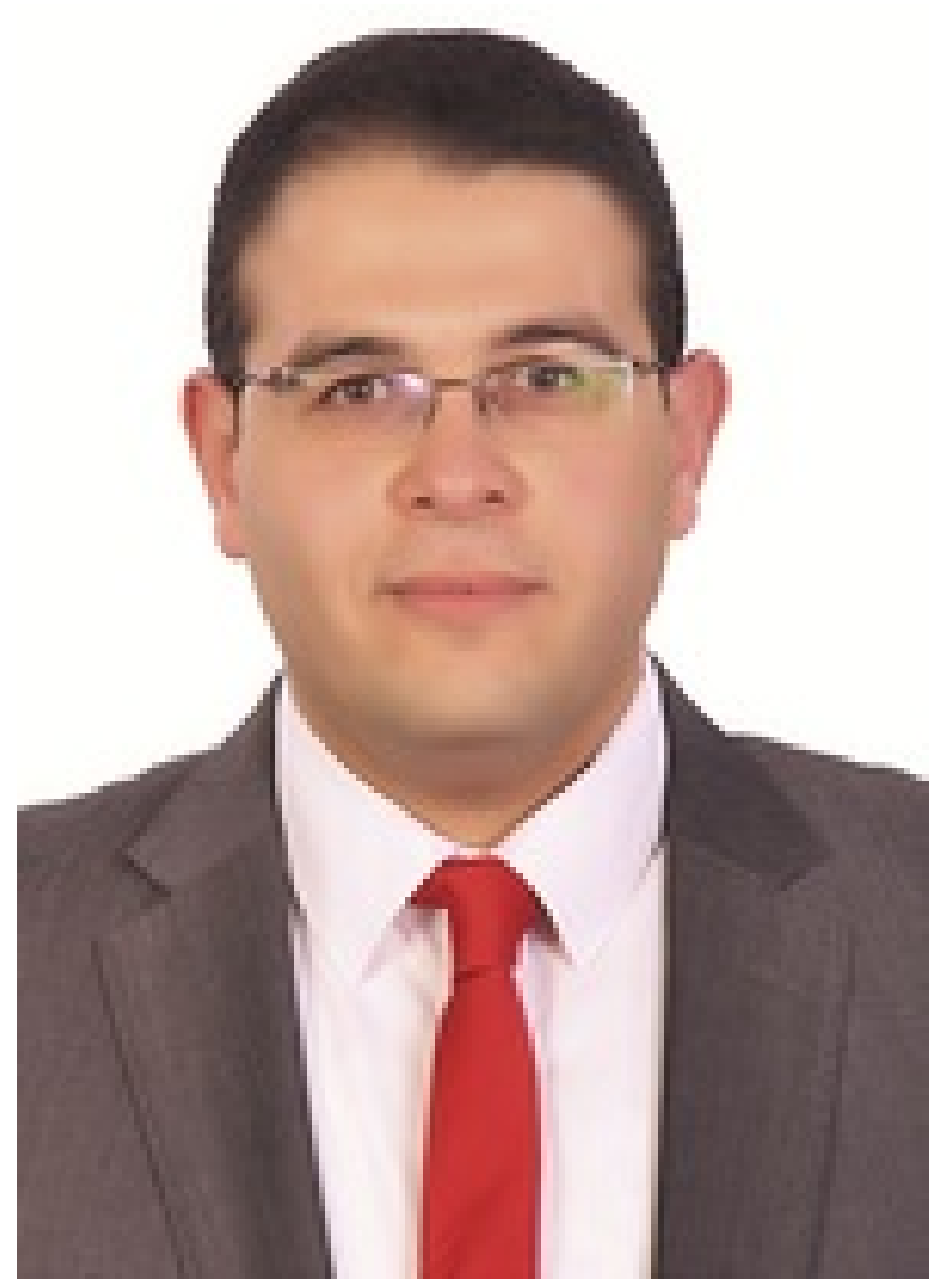

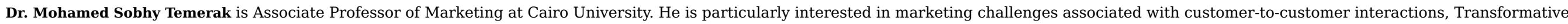

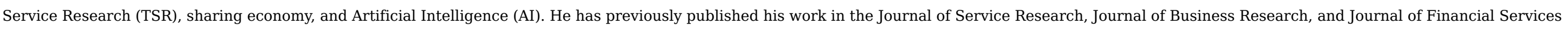
Marketing

\section{Appendix B. Supplementary data}

The following is the Supplementary data to this article:

Multimedia Component 1

Multimedia component 1

alt-text: Multimedia component 1 


\section{Highlights}

- Immediate benefits of attracting heterogeneous customers should be outweighed against other unforeseen costs.

- Reactions to dissimilar customers need to be examined from a dual-perspective.

- Resort guests may have their own justifications to suppress or express their prejudice against dissimilar others.

- Reactions to dissimilar customers may vary from avoid visiting a resort to maintaining social distance.

- Observable characteristics in other unknown customers do not operate in isolation, but they interact with one another.

\section{Queries and Answers}

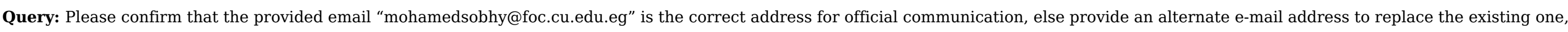
because private e-mail addresses should not be used in articles as the address for communication.

Answer: Yes, this is my official email at Cairo University

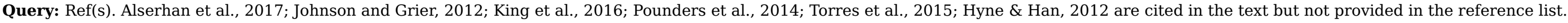
Please provide them in the reference list or delete these citations from the text.

Answer: They are actually provided in the reference list (1)

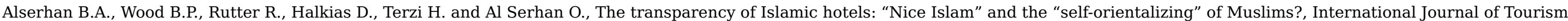

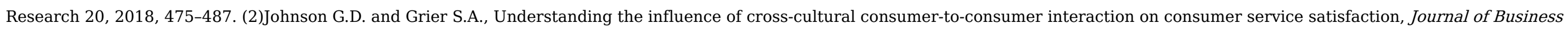

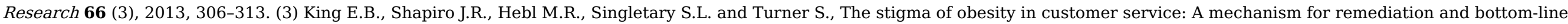

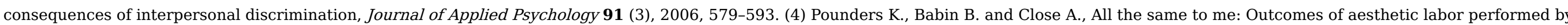

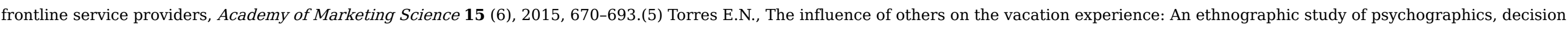

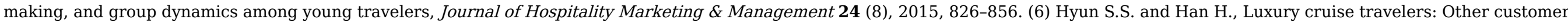
perceptions, Journal of Travel Research 54 (1), 2015, 107-121.

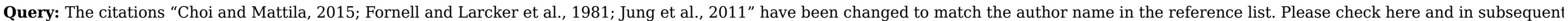
occurrences, and correct if necessary.

Answer: Please note that Choi and Mattila (2016) not 2015. All references checked for consistency. Also, Jung et al. (2011) should be changed to Jung and Yoon (2011)

Query: Please note that "Fig. 1" were not cited in the text. Please check that the citation(s) suggested by the copyeditor are in the appropriate place, and correct if necessary.

Answer: This has been added at the end of section 2.3. Please re-locate figure 1 before section 2.4.

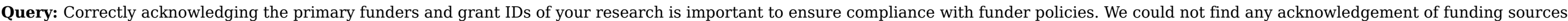
in your text. Is this correct?

Answer: There is no funding sources

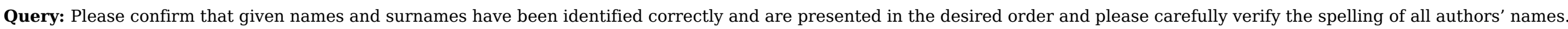

Answer: Yes

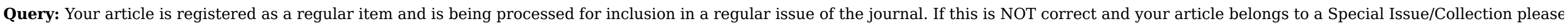


